\title{
Characterization of aerosol particles at Cabo Verde close to sea level and at the cloud level - Part 1: Particle number size distribution, cloud condensation nuclei and their origins
}

\author{
Xianda Gong, Heike Wex, Jens Voigtländer, Khanneh Wadinga Fomba, Kay Weinhold, Manuela van Pinxteren, \\ Silvia Henning, Thomas Müller, Hartmut Herrmann, and Frank Stratmann \\ Leibniz Institute for Tropospheric Research, Leipzig, Germany
}

Correspondence: Xianda Gong (gong@tropos.de)

Received: 19 June 2019 - Discussion started: 11 July 2019

Revised: 7 December 2019 - Accepted: 13 January 2020 - Published: 6 February 2020

\begin{abstract}
In the framework of the MarParCloud (Marine biological production, organic aerosol particles and marine clouds: a Process Chain) project, measurements were carried out on the islands of Cabo Verde (a.k.a. Cape Verde) to investigate the abundance, properties and sources of aerosol particles in general, and cloud condensation nuclei $(\mathrm{CCN})$ in particular, both close to sea level and at the cloud level.

A thorough comparison of particle number concentration (PNC), particle number size distribution (PNSD) and $\mathrm{CCN}$ number concentration $\left(N_{\mathrm{CCN}}\right)$ at the Cape Verde Atmospheric Observatory (CVAO, sea-level station) and Monte Verde (MV, cloud-level station) reveals that during times without clouds the aerosols at CVAO and MV are similar and the boundary layer is generally well mixed. Therefore, data obtained at CVAO can be used to describe the aerosol particles at cloud level. Cloud events were observed at MV during roughly $58 \%$ of the time, and during these events a large fraction of particles was activated to cloud droplets.

A trimodal parameterization method was deployed to characterize PNC at CVAO. Based on number concentrations in different aerosol modes, four well-separable types of PNSDs were found, which were named the marine type, mixture type, dust type 1 and dust type2. Aerosol particles differ depending on their origins. When the air masses came from the Atlantic Ocean, sea spray can be assumed to be one source for particles besides new particle formation. For these air masses, PNSDs featured the lowest number concentration in Aitken, accumulation and coarse modes. Particle number concentrations for sea spray aerosol (SSA, i.e., the coarse mode for these air masses) accounted for about $3.7 \%$ of $N_{\mathrm{CCN}, 0.30 \%}$ (CCN number concentration at $0.30 \%$ super-
\end{abstract}

saturation) and about $1.1 \%$ to $4.4 \%$ of $N_{\text {total }}$ (total particle number concentration). When the air masses came from the Sahara, we observed enhanced Aitken, accumulation and coarse mode particle number concentrations and overall in-

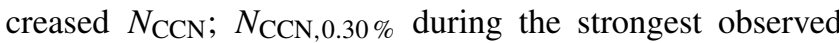
dust periods is about 2.5 times higher than that during marine periods. However, the particle hygroscopicity parameter $\kappa$ for these two most different periods shows no significant difference and is generally similar, independent of air mass.

Overall, $\kappa$ averaged 0.28 , suggesting the presence of organic material in particles. This is consistent with previous model work and field measurements. There is a slight increase in $\kappa$ with increasing particle size, indicating the addition of soluble, likely inorganic, material during cloud processing.

\section{Introduction}

Clouds in the atmosphere are formed when excess water vapor condenses on aerosol particles that serve as cloud condensation nuclei (CCN). Back in the 1970s, Twomey (1974) described that an increase in the number of aerosol particles that activate to clouds led to more but smaller droplets. Albrecht (1989) suggested that smaller droplets then cause suppression in the formation of precipitation, leading to a prolonged cloud lifetime. Both of these effects enhance the shortwave reflection of clouds, i.e., they lead to a cooling of the atmosphere. In particular, warm low-level clouds located in the boundary layer constitute an important role in the cool- 
ing effects due to their abundance and strong cloud albedo effect (Christensen et al., 2016). In recent years, many more aspects of aerosol-cloud interactions were discussed. Considerable progress has been made in understanding the chemical composition and microphysical properties of aerosol particles that enable them to act as CCN (Andreae and Rosenfeld, 2008). The ability of particles to act as CCN is largely controlled by aerosol particle size rather than composition (Dusek et al., 2006). However, we still lack understanding of the overall roles of aerosol particles, clouds and their interactions in the climate system, which contribute to the largest uncertainties to estimate the Earth's energy budget (Stocker, 2014).

Mineral dust from deserts contributes largely to tropospheric aerosols and impacts the air quality of several regions, even of the globe (Ginoux et al., 2001; Huang et al., 2006; Tanaka and Chiba, 2006). The largest dust source is located in the Northern Hemisphere in the Sahara and Sahel regions (Goudie and Middleton, 2001; Prospero et al., 2002; Ginoux et al., 2012), with millions of tonnes of mineral dust being transported to Europe and the Middle East, as well as to the Americas, yearly (including the Caribbean and the Amazon basin) (Swap et al., 1992; Salvador et al., 2013; Wex et al., 2016). Mineral dust aerosol in the atmosphere can affect the Earth's radiative budget by directly scattering and absorbing solar and infrared radiation (Goudie and Middleton, 2001; Shao et al., 2011). On the other hand, it can modify cloud properties, i.e., serve as $\mathrm{CCN}$ or ice-nucleating particles (INPs) (Sassen et al., 2003; DeMott et al., 2003). Karydis et al. (2011) found that the predicted annual average contribution of insoluble mineral dust to $\mathrm{CCN}$ number concentration in cloud-forming areas is up to $40 \%$ over northern Africa and Asia (Arabian Peninsula and Gobi Desert).

Based on a 3-week field campaign in summer 1973 at Cabo Verde, Jaenicke and Schütz (1978) investigated the aerosol properties, such as total size distribution, mass, sea salt, mineral and organic compound content, and found that a total mass of $100 \mu \mathrm{g} \mathrm{m}^{-3}$ during dust plumes is 5 times higher than the $20 \mu \mathrm{g} \mathrm{m}^{-3}$ of clean air masses. Kandler et al. (2011b) also found that the total particle mass concentration during dust plumes was raised by a factor of more than 10 over the maritime mass concentration, demonstrating a strong impact of Saharan dust advection on the aerosol load at Cabo Verde. Significant seasonal intrusions of dust from northwest Africa affect Cabo Verde at surface level from October till March. An hourly $\mathrm{PM}_{10}$ value reached up to $710 \mu \mathrm{g} \mathrm{m}^{-3}$ at surface level at Cabo Verde (Gama et al., 2015). Schladitz et al. (2011b) found that mineral dust particles were mainly in the coarse mode. The variation in the amount of mineral dust is much larger than the variation in the sea salt content in the coarse mode. Also pesticides, polycyclic aromatic hydrocarbons (PAHs), and polychlorinated biphenyl (PCB), all of which originate from the Sahara and Sahel regions, can be incorporated with Saharan dust and then transported to Cabo Verde (Garrison et al., 2014).
Many studies investigated the marine aerosol in laboratory or in field measurements, but few of them were carried out at Cabo Verde or nearby regions. Due to the vast coverage of the Earth's surface by the oceans, wind-driven particle production on the ocean surface is one of the largest global sources of primary atmospheric particle on a mass concentration basis (Warneck, 1999; Modini et al., 2015). Together with newly formed particles originating from gaseous precursors which can also be emitted from the ocean, this sea spray aerosol (SSA) contributes to marine aerosols. Ambient measurements and laboratory studies indicated that the resulting marine aerosol with less than $10 \mu \mathrm{m}$ diameter can have a trimodal size distribution, which suggests that several mechanisms are involved in marine aerosol production (Prather et al., 2013; Quinn et al., 2015; Brooks and Thornton, 2018). Marine aerosol number and mass concentrations, chemical composition, and optical and cloud-nucleating properties can be changed during transportation, e.g., marine aerosol can carry continental emissions up to thousands of kilometers downwind (Quinn et al., 2015). Marine aerosol impacts Earth's radiation balance by directly scattering solar radiation (Quinn et al., 2017). Ocean physics, biology and chemistry ultimately control both particle hygroscopicity (Fuentes et al., 2011) and the number of particles that can act as CCN and INPs (Andreae and Rosenfeld, 2008; Wilson et al., 2015; DeMott et al., 2016) in the marine aerosol. On a global basis, SSA makes a contribution of less than $30 \%$ to the CCN population (Quinn et al., 2017).

Marine aerosol is the second important aerosol source at Cabo Verde when looking at particle mass (Fomba et al., 2014; Salvador et al., 2016). There is always a background of marine aerosol present at Cabo Verde (Kandler et al., 2011a). Based on a 5-year measurement at Cabo Verde, Fomba et al. (2014) found that the mean mass concentration of sea salt was $11.00 \pm 5.10 \mathrm{\mu g} \mathrm{m}^{-3}$ (corresponding to total mass of $47.20 \pm 55.50 \mu \mathrm{g} \mathrm{m}^{-3}$ ). Additionally during summer, elevated concentrations of organic material were observed to originate from marine emissions. A summer maximum was observed for non-sea-salt sulfate, and it was connected to periods when air mass inflow was predominantly of marine origin, indicating that marine biogenic emissions were a significant source. Schladitz et al. (2011b) found that the Aitken mode and accumulation mode particles were mainly composed of marine aerosol, whereas coarse mode particles were composed of sea salt and a variable fraction of Saharan mineral dust.

As outlined above, Saharan dust and sea salt dominate $\mathrm{PM}_{10}$ particle composition (more than $70 \%$ ) near the surface at Cabo Verde (Fomba et al., 2014; Salvador et al., 2016). In addition, Cabo Verde is rich in other kinds of aerosols from both continental and marine sources. Biomass burning aerosols produced from October to November in subSahelian latitudes had a clear influence on the content of elemental carbon (EC) recorded at Cabo Verde but a small impact on $\mathrm{PM}_{10}$ (Salvador et al., 2016), as particles originating from the biomass burning layer usually stay at high 
altitude (1500-5000 m) (Tesche et al., 2009; Heinold et al., 2011; Lieke et al., 2011).

Overall, there are diverse sources of less or more hygroscopic particles which might contribute to aerosols at Cabo Verde. Pringle et al. (2010) used an atmospheric chemistry model to simulate global fields of the effective hygroscopicity parameter, represented by $\kappa$ (Petters and Kreidenweis, 2007), which roughly describes the influence of chemical composition on CCN activity of aerosol particles. An annual cycle of monthly-mean $\kappa$ values at the surface of Cabo Verde was reported in Pringle et al. (2010). The only field measurement of particle hygroscopicity at Cabo Verde was carried out by Schladitz et al. (2011a). Here, these model results and field measurement values will be compared with those obtained from in situ measurements during our measurement campaign in the framework of the MarParCloud (Marine biological production, organic aerosol particles and marine clouds: a Process Chain) project.

The atmospheric boundary layer (ABL) is the region in the lowest part of the troposphere (below $1000 \mathrm{~m}$ above the ground) where the Earth's surface strongly influences temperature, moisture and wind through the turbulent transfer of air masses. Most particles are emitted or formed in the ABL with temporally varying sources (Rosati et al., 2016b). Extensive data sets from ground-based aerosol property studies are available. One major point of interest is to know whether ground-based measurements can be used to infer aerosol properties at cloud level. Previous field measurements at Po Valley and the Netherlands found that during the development of a newly mixed layer the estimation of altitudespecific data from surface measurements may be problematic (Rosati et al., 2016a, b). Once the ABL was fully mixed, a constant extinction coefficient (Rosati et al., 2016b) and particle hygroscopicity (Rosati et al., 2016a) were observed at all altitudes within the ABL. Wex et al. (2016) found, for marine aerosol on Barbados, that the particle number size distribution (PNSD) on the ground and throughout the subcloud level showed good agreement.

During the MarParCloud project, we set up two measurement stations, one close to the sea level (10 ma.s.l.) and one on a mountaintop (744 $\mathrm{m}$ a.s.1.), to characterize aerosol properties, including particle number concentration (PNC), PNSD and CCN number concentration $\left(N_{\mathrm{CCN}}\right)$. In addition, a measurement from a kite and balloon (Helikite) was carried out to characterize vertical profiles of meteorological parameters at Cabo Verde. This offered a unique opportunity to compare particle properties close to the sea level and higher up in the marine boundary layer (MBL).

In a series of companion papers (Gong et al., 2020), we aim to provide a quantitative understanding regarding the abundance, properties and source of aerosol particles in general, and CCN and INPs in particular, close to both sea-level and cloud-level heights. In this paper, we will (1) compare aerosol properties measured close to sea level and at a mountaintop to examine the representativeness of ground-based measurements to the MBL and (2) present a thorough characterization of $\mathrm{CCN}$ with respect to their hygroscopicity and number concentrations for different air masses. Both of these will be presented here for the Cabo Verde for the first time. In a companion paper, we will examine the abundance and properties of INPs from several different sources, namely sea surface microlayer and under layer water from the ocean, airborne close to sea and cloud level, and cloud water of warm cloud. This study is the first in a series of publications to come from the MarParCloud project. For more information about the campaign itself and a more detailed analysis of the meteorological situation, we refer the reader to the overview paper (van Pinxteren et al., 2019), which will also cover a thorough size-resolved chemical composition analysis of particles close to the sea level and on the mountaintop.

\section{Experiment and methods}

\subsection{Sampling sites and campaign setup}

The measurements were carried out on São Vicente island in Cabo Verde from 13 September to 13 October 2017. Located in the Atlantic Ocean, São Vicente island is $\sim 900 \mathrm{~km}$ off the African coast. The region experiences constant northeasterly winds. The average annual temperature at Cabo Verde is $23.6 \pm 4.0^{\circ} \mathrm{C}$ (mean \pm 1 standard deviation). It is an arid region with a maximum of $24-350 \mathrm{~mm}$ rainfall per year. The precipitation frequency is about 3 to 10 events annually, mainly between August and October (Carpenter et al., 2010; Fomba et al., 2013). More details of the meteorological conditions at Cabo Verde can be found in Carpenter et al. (2010).

Three measurement stations were set up at Cabo Verde, i.e., Cape Verde Atmospheric Observatory (CVAO), Monte Verde station (MV) and an ocean station (OS, this station will be discussed only in the companion paper). CVAO $\left(16^{\circ} 51^{\prime} 49^{\prime \prime} \mathrm{N}, 24^{\circ} 52^{\prime} 02^{\prime \prime} \mathrm{W}\right)$ is located at the northeastern shore of the São Vicente island, $70 \mathrm{~m}$ from the coastline at about $10 \mathrm{~m}$ a.s.l. An aerosol $\mathrm{PM}_{10}$ inlet, employed to remove particles larger than $10 \mu \mathrm{m}$ in aerodynamic diameter, was installed on top of a $32 \mathrm{~m}$ tower. Downstream of the aerosol inlet there was a vertical stainless-steel sampling pipe (32 $\mathrm{m}$ long, $1 / 2 \mathrm{in}$. outer diameter), installed together with a diffusion dryer, which was placed directly on top of the measurement container. Aerosol entered the inlet on top of the mast and was transported through the tube and the dryer. Downstream of the dryer and inside of the container, the aerosol was split isokinetically and distributed to various instruments, including a mobility particle sizer spectrometer (MPSS), an aerodynamic particle sizer (APS) and a cloud condensation nuclei counter (CCNC). Besides, airborne measurements were carried out at CVAO using a Helikite to characterize the vertical profiles of temperature, relative humility (RH), and wind speed and direction. 
MV $\left(16^{\circ} 52^{\prime} 11^{\prime \prime} \mathrm{N}, 24^{\circ} 56^{\prime} 02^{\prime \prime} \mathrm{W}\right)$ is located on the top of Monte Verde (744 ma.s.l.), $\sim 7 \mathrm{~km}$ away to the west of CVAO. An aerosol inlet was installed on the roof of a building, which overall had a cut-off size of $4 \mu \mathrm{m}$. A vertical stainless-steel sampling pipe ( $2 \mathrm{~m}$ long, 1 in. diameter) and a diffusion dryer were placed downstream of the aerosol inlet. Downstream of the dryer and inside the building, the sample aerosol was split isokinetically to an MPSS and CCNC. An overview of the sampling site and instruments is given in Table 1. In the following, we will briefly introduce the different measurement techniques applied in this study, including calibrations, measurements and data processing.

\subsection{Balloon measurements}

The vertical profile of meteorological parameters was taken at CVAO. The measurements were achieved using a $16 \mathrm{~m}^{3}$ Helikite (Allsopp Helikites Ltd, Hampshire, UK), a unique combination of a tethered balloon and a kite. Helikites are designed to be operated under extreme weather conditions. The kite was attached to a $3 \mathrm{~mm}$ Dyneema rope $(2000 \mathrm{~m}$ long, $4.6 \mathrm{~g} \mathrm{~m}^{-1}$, Lyros D-Pro $3 \mathrm{~mm}$, breaking load $950 \mathrm{daN}$, working elongation $<1 \%$ ) and operated by a winch. Under calm conditions, the Helikite has a net load capacity of $\sim 8 \mathrm{~kg}$. Under windy condition, the pull increases significantly, and the net load capacity reaches about $16 \mathrm{~kg}$ at $6 \mathrm{~m} \mathrm{~s}^{-1}$. Depending on the prevailing conditions, meteorological measurements of up to an altitude of about $1200 \mathrm{~m}$ could be carried out. The measuring system, built by the Leibniz Institute for Tropospheric Research (TROPOS), was attached to the rope $20 \mathrm{~m}$ below the Helikite. All sensors were selected and tested individually in the laboratory at TROPOS. Wind speed was measured using a differential pressure sensor together with a pitot tube; wind direction was determined from an orientation sensor (compass) of a wind vane. Data were recorded with a measuring frequency of $2 \mathrm{~Hz}$, stored in a Secure Digital memory card and additionally transmitted to a ground station (via Digi XBee radio modules). Our aim was to characterize the atmospheric boundary layer in terms of mixing state, which can provide insights into uncertainties regarding the connection between ground-based measurements and the free troposphere.

\subsection{Particle number size distribution}

PNSDs were measured in the size range from $10 \mathrm{~nm}$ to $10 \mu \mathrm{m}$ using a TROPOS-type MPSS (Wiedensohler et al., 2012) and an APS (aerodynamic particle sizer, model 3321, TSI Inc., St. Paul, MN, USA). The APS data accounted for the multiple charge correction of MPSS data in the inversion of measured PNSD (Wiedensohler, 1988; Pfeifer et al., 2016). The combined PNSD is then given on the basis of the volume equivalent particle diameter. More details about the combined MPSS and APS PNSDs can be found in the Supplement and Schladitz et al. (2011b). Size-dependent parti- cle losses caused by diffusion, deposition and sedimentation within the inlet were corrected for by utilizing the empirical particle loss calculator (von der Weiden et al., 2009). The size-dependent particle losses are shown in the Supplement, Fig. S1. Total particle number concentrations $\left(N_{\text {total }}\right)$ were calculated from the measured PNSDs accounting for the size-dependent particle losses. The MPSS and APS were calibrated before, during and after the intensive field study. Overall, fewer than $3 \%$ of the particles were lost when passing the inlet. More details about calibration methods can be found in Wiedensohler et al. (2018).

\subsection{Cloud condensation nuclei}

$N_{\mathrm{CCN}}$ was measured using a cloud condensation nuclei counter (CCNC, Droplet Measurement Technologies, Boulder, USA; Roberts and Nenes, 2005). The CCNC is a cylindrical continuous-flow thermal-gradient diffusion chamber, establishing a constant streamwise temperature gradient to adjust a quasi constant centerline supersaturation. The sampled aerosol particles are guided within a sheath flow through this chamber and can become activated to droplets, depending on the supersaturation level and the ability of the particles to act as $\mathrm{CCN}$.

During our study, the supersaturation was varied between $\sim 0.15 \%$ and $\sim 0.79 \%$ at a constant total flow rate of $0.5 \mathrm{~L} \mathrm{~min}^{-1}$. To ensure stable column temperature, the first $5 \mathrm{~min}$ and the last $30 \mathrm{~s}$ of each $12 \mathrm{~min}$ long measurement at each supersaturation were excluded from the data analysis. The remaining data points were averaged. A supersaturation calibration (following the protocol by Gysel and Stratmann, 2013) was done at the cloud laboratory of the TROPOS prior to and after the measurement campaign in order to determine the relationship between the temperature gradient along the column and the effective supersaturation. Calibrated supersaturation set points were $0.15 \%, 0.20 \%, 0.30 \%, 0.50 \%$ and $0.70 \%$ of CVAO CCNC and $0.15 \%, 0.21 \%, 0.33 \%, 0.56 \%$, and $0.79 \%$ of MV CCNC. These values were used for further calculations.

According to Köhler theory (Köhler, 1936), whether or not a particle can act as a $\mathrm{CCN}$ depends on its dry size, chemical composition and the maximum supersaturation it encounters. Petters and Kreidenweis (2007) presented a method to describe the relationship between particle dry diameter and $\mathrm{CCN}$ activity using the hygroscopicity parameter $\kappa ; \kappa$ values reported in this study were calculated as follows, assuming the surface tension of the examined solution droplets, $\sigma_{\mathrm{s} / \alpha}$, to be that of pure water:

$$
\kappa=\frac{4 A^{3}}{27 d_{\text {crit }}^{3} \ln ^{2} S}
$$

with

$$
A=\frac{4 \sigma_{\mathrm{s} / \alpha} M_{\omega}}{R T \rho_{\omega}},
$$


Table 1. Measured and derived parameters and the respective instrumentation used at CVAO and MV. Note, SS represents supersaturation.

\begin{tabular}{|c|c|c|c|c|c|}
\hline $\begin{array}{l}\text { Measurement } \\
\text { site }\end{array}$ & Location & Parameter & Abbreviation & Instrument & $\begin{array}{l}\text { Measurement } \\
\text { range }\end{array}$ \\
\hline CVAO & $\begin{array}{l}16^{\circ} 51^{\prime} 49^{\prime \prime} \mathrm{N}, 24^{\circ} 52^{\prime} 02^{\prime \prime} \mathrm{W} \text {; } \\
\text { inlet height } 42 \mathrm{~m} \text { a.s.l. }\end{array}$ & $\begin{array}{l}\text { Particle number size distribution } \\
\text { Particle number concentration } \\
\text { CCN number concentration } \\
\text { Particle hygroscopicity } \\
\text { Vertical profile of temperature and } \mathrm{RH}\end{array}$ & $\begin{array}{l}\text { PNSD } \\
N_{\text {total }} \\
N_{\mathrm{CCN}} \\
\kappa \\
-\end{array}$ & $\begin{array}{l}\text { MPSS and APS system } \\
\text { Integrated PNSD } \\
\text { CCNC } \\
\text { CCNC with } \\
\text { MPSS and APS system } \\
\text { Balloon }\end{array}$ & $\begin{array}{l}10 \text { to } 10000 \mathrm{~nm} \\
- \\
- \\
\mathrm{SS}=0.15 \%, 0.20 \%, 0.30 \%, \\
0.50 \% \text {, and } 0.70 \% \\
\text { Height up to } 1200 \mathrm{~m}\end{array}$ \\
\hline MV & $\begin{array}{l}16^{\circ} 52^{\prime} 11^{\prime \prime} \mathrm{N}, 24^{\circ} 56^{\prime} 02^{\prime \prime} \mathrm{W} \text {; } \\
\text { inlet height } 746 \mathrm{~m} \text { a.s.l. }\end{array}$ & $\begin{array}{l}\text { Particle number size distribution } \\
\text { Particle number concentration } \\
\text { CCN number concentration } \\
\text { Particle hygroscopicity }\end{array}$ & $\begin{array}{l}\text { PNSD } \\
N_{\text {total }} \\
N_{\mathrm{CCN}} \\
\kappa\end{array}$ & $\begin{array}{l}\text { MPSS system } \\
\text { Integrated PNSD } \\
\text { CCNC } \\
\text { CCNC with } \\
\text { MPSS system }\end{array}$ & $\begin{array}{l}10 \text { to } 850 \mathrm{~nm} \\
- \\
- \\
\mathrm{SS}=0.15 \%, 0.21 \%, 0.33 \% \text {, } \\
0.56 \% \text {, and } 0.79 \%\end{array}$ \\
\hline
\end{tabular}

where $d_{\text {crit }}$ is the critical diameter above which all particles activate into cloud droplets for a given supersaturation. $S$ is the supersaturation. $M_{\omega}$ and $\rho_{\omega}$ are the molar mass and density of water, respectively, and $R$ and $T$ are the ideal gas constant and the absolute temperature, respectively. To derive $d_{\text {crit }}$, simultaneously measured $N_{\mathrm{CCN}}$ and PNSD are used. Therefore, it is assumed that all particles in the neighborhood of a given particle diameter have a similar $\kappa$, meaning that the aerosol particles are internally mixed. At a given supersaturation, a particle can be activated to a droplet once its dry size is equal to or larger than $d_{\text {crit }}$. Therefore, $d_{\text {crit }}$ is the diameter at which $N_{\mathrm{CCN}}$ is equal to the value of the cumulative particle number concentration, determined via integration from the upper towards the lower end of the PNSD. Values for $\kappa$ can be calculated with $d_{\text {crit }}$ and the corresponding supersaturation based on Eq. (1). The inferred $\kappa$ values correspond to particles with sizes of roughly $d_{\text {crit }}$. The uncertainty in $\kappa$, which results from uncertainties of the PNSD measurements and the supersaturations of the CCNC, was determined by applying a Monte Carlo simulation (MCS) in a similar fashion as done by Kristensen et al. (2016) and Herenz et al. (2018). A detailed description of this method is provided in the Supplement. Note that the particle losses inside the CCNC (discussed in Rose et al., 2008) were also considered before $\kappa$ was calculated.

\section{Results and discussion}

\subsection{Overview of the meteorology}

Time series of meteorological parameters, including the wind speed, temperature and $\mathrm{RH}$ at $\mathrm{CVAO}$ and $\mathrm{MV}$, as well as wind direction at CVAO, are shown in Fig. 1. The wind speed varied from 0.6 to $9.7 \mathrm{~m} \mathrm{~s}^{-1}$, with a mean of $6.0 \mathrm{~m} \mathrm{~s}^{-1}$ at CVAO. The variation in wind speed at MV is similar to that at CVAO. Figure 2 shows the wind rose plot based on hourly average of wind speed and direction at CVAO. Clearly, the CVAO station experienced constant northeasterly winds during this campaign. The temperature and $\mathrm{RH}$ were measured by a digital temperature and humidity sensor (Davis Instruments, 7346.070). The accuracy of the temperature sensor is $\pm 0.3^{\circ} \mathrm{C}$; the accuracy of the humidity sensor is $\pm 2 \%$ below $90 \%$ and $\pm 4 \%$ above $90 \%$. The temperature and $\mathrm{RH}$ at CVAO varied from 25.6 to $28.3^{\circ} \mathrm{C}$ and $70.0 \%$ to $90.5 \%$, with means of $26.6^{\circ} \mathrm{C}$ and $81.0 \%$, respectively. Obviously, temperature at $\mathrm{MV}$ was lower than that at $\mathrm{CVAO}$, ranging from 18.9 to $25.4^{\circ} \mathrm{C}$, with a mean of $21.2^{\circ} \mathrm{C}$. The measured RH was $100 \%$ during more than half of the campaign at MV. Note that due to the instrument detection limit, $\mathrm{RH}=100 \%$ is not accurate. However, the $\mathrm{RH}=100 \%$ result indicates that the MV station was often in a cap cloud. More precise determination of cloud events and influences of cloud on aerosol particles will be discussed in Sect. 3.3. Note that all the times presented here are in UTC (corresponding to $\mathrm{LT}+1)$. For better comparison, all PNC and $N_{\mathrm{CCN}}$ data reported in this study are given for standard temperature and pressure (STP, $0^{\circ} \mathrm{C}$ and $1013.25 \mathrm{hPa}$ ).

During the MarParCloud campaign, 19 vertical profiles on 10 different days were taken. Profiles of up to about $1200 \mathrm{~m}$ could be measured. The inversion layer heights were determined by the measurements. The MBL was typically well mixed with boundary layer heights between about 550 and $1100 \mathrm{~m}$, as shown by blue rectangles in Fig. 1. It is indicated that there were three cases of a decoupled boundary layer during the whole campaign, as shown by red dots in Fig. 1. Therefore, to be sure to represent aerosol collected at Cabo Verde, we used backward trajectories starting at $200 \mathrm{~m}$ altitude to represent MBL air mass origins in this study. Exemplary data from one balloon measurement can be found in the Supplement (Sect. S3).

\subsection{Particle characterization}

This section will first discuss PNSDs and PNC at CVAO. A well-known trimodal lognormal parameterization method is adopted to characterize the temporal variation in PNC in three modes. It is used to classify the particles into different types based on PNC in different modes. Lastly, to get insights into possible particle sources, we studied the air 


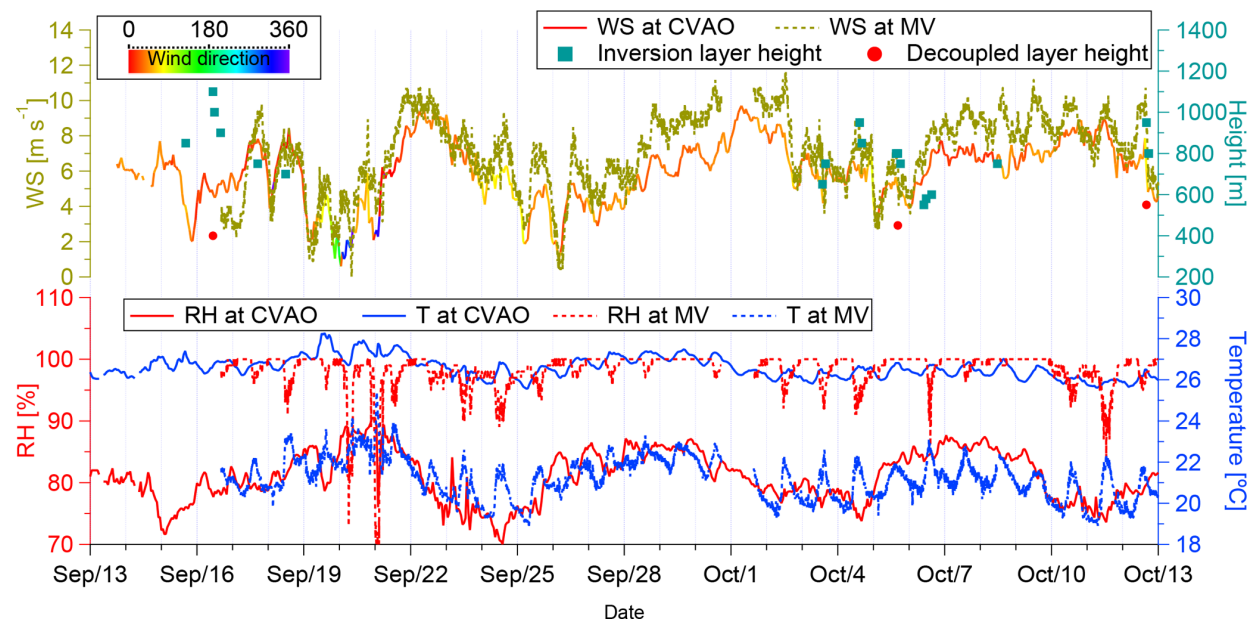

Figure 1. Time series of wind speed (WS), wind direction (CVAO only), RH and temperature. Parameters measured at CVAO are shown by solid lines and at MV in dashed lines. Time series of inversion layer height are shown by blue squares and decoupled layer height in red dots.

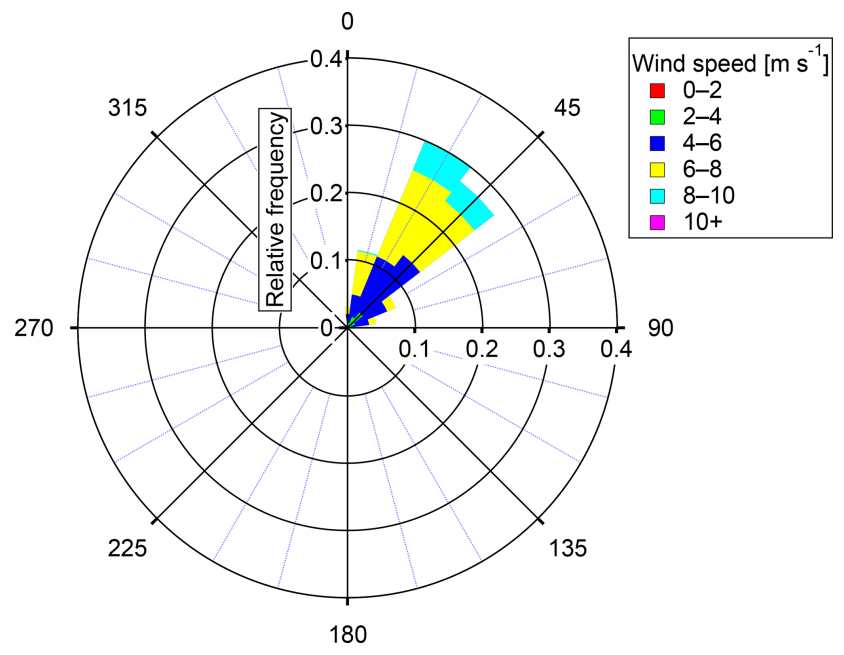

Figure 2. Wind rose based on hourly averages of wind speed and direction (measured at CVAO).

mass origin and transport through backward trajectory analysis. Calculations were performed with the HYSPLIT (HYbrid Single-Particle Lagrangian Integrated Trajectory) model (Stein et al., 2015; Rolph, 2003).

\subsubsection{Particle number size distribution and concentration}

Particle size is one of the most important parameters to characterize the atmospheric aerosol. Figure 3 presents contour plots for PNSDs of supermicron particles in Fig. 3a and submicron particles in Fig. 3b. In order to show details of supermicron particles, we adopted different color bar scales for submicron and supermicron particles. Most of the time, two submicron modes (Aitken and accumulation mode) and one supermicron mode (coarse mode) are observed. The Aitken mode is observed from $\sim 10$ to $\sim 80 \mathrm{~nm}$, and the accumulation mode is observed from $\sim 80$ to $\sim 1000 \mathrm{~nm}$. However, from 03:30 to 20:00 21 September and from 09:30 28 September to 18:30 30 September, the submicron particles only exhibited a unimodal distribution. The supermicron particles exhibited a high concentration during those periods. $N_{\text {total }}$ was changed significantly, from $\sim 200$ to $\sim 1500 \mathrm{~cm}^{-3}$ with a median of $\sim 700 \mathrm{~cm}^{-3}$, shown as black line in Fig. $3 \mathrm{~b}$.

Particles of different sizes have different formation routes, sources and behaviors. To better define the modes of our data, we fitted the PNSDs to three lognormal functions. The lognormal distribution was expressed by Seinfeld and Pandis (2016), and the parameterization function is as follows:

$$
\begin{aligned}
& \frac{\mathrm{d} N}{\mathrm{~d} \log D_{\mathrm{p}}}=\sum_{i=1}^{n} \frac{N_{i}}{\sqrt{2 \pi} \log _{10} \sigma_{i}} \\
& \quad \exp \left(-\frac{\left(\log _{10} D_{\mathrm{p}}-\log _{10} D_{i}\right)^{2}}{2\left(\log _{10} \sigma_{i}\right)^{2}}\right),
\end{aligned}
$$

where $N_{i}$ is the total number concentration of the $i$ th mode, $D_{i}$ is the geometric mean diameter of the $i$ th mode and $\sigma_{i}$ is the geometric standard deviation of the $i$ th mode distribution. Every PNSD was individually parameterized by a trimodal distribution, where the number of $i, i=1,2,3$, stands for Aitken, accumulation or coarse mode, receptively. For each PNSD, we searched for an optimal fitting function, until the coefficient of determination $\left(R^{2}\right)$ was larger than 0.97 .

Time series of PNC in Aitken mode $\left(N_{\text {Aitken }}\right)$, accumulation mode $\left(N_{\text {accumulation }}\right)$ and coarse mode $\left(N_{\text {coarse }}\right)$, together with sum of $N_{i}$ and measured $N_{\text {total }}$, are shown in Fig. 4. Due to the unimodal distribution of submicron particles from 03:30 to 20:00 21 September and from 09:30 28 September to 18:30 30 September, the trimodal lognormal fitting did not work properly, so we did a bimodal lognormal fitting instead, 

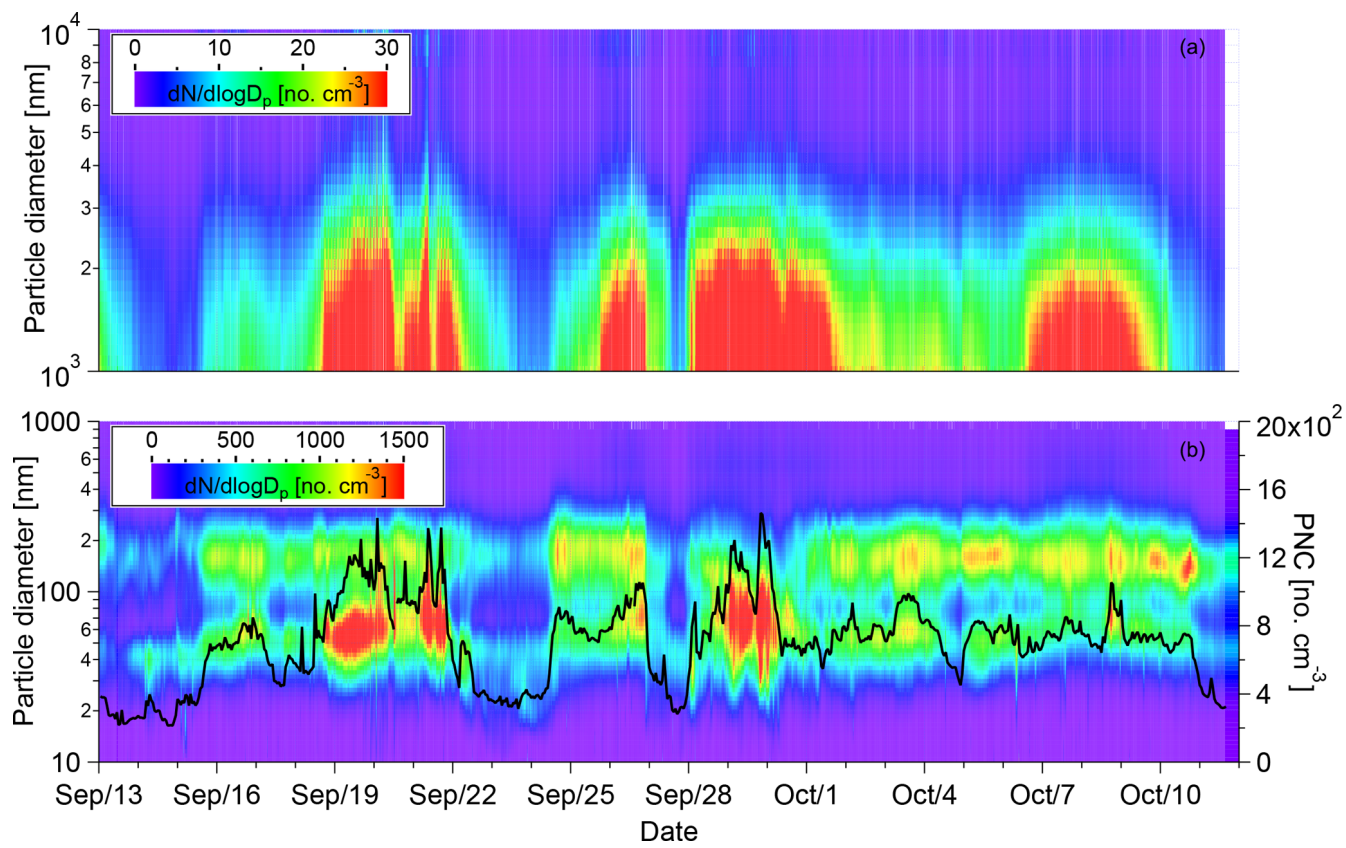

Figure 3. Contour plots for PNSDs of $1000 \mathrm{~nm}$ to $10 \mu \mathrm{m}$ in panel (a) and 10 to $1000 \mathrm{~nm}$ in panel (b). The color scale indicates $\mathrm{d} N / \mathrm{d} l o g D_{\mathrm{p}}$ in cubic centimeters $\left(\mathrm{cm}^{-3}\right)$. Time series of $N_{\text {total }}$ is shown by the black line in panel (b).

with one submicron mode ( $N_{\text {submicron}}$, as shown by purple dots) and one coarse mode.

PNC showed large variability during our measurement. $N_{\text {Aitken }}$ and $N_{\text {accumulation }}$ varied from 41 to 789 and 89 to $639 \mathrm{~cm}^{-3}$, with medians of 244 and $354 \mathrm{~cm}^{-3}$, respectively. Generally, Aitken mode particles are produced by homogeneous and heterogeneous nucleation processes, formed during natural gas-to-particle condensation. Aitken mode particles are transferred to the accumulation mode through cloud processing (Hoppel et al., 1994). And accumulation mode particles are furthermore formed by coagulation of smaller particles or condensation of vapors onto existing particles, during which they grow into that size range (Seinfeld and Pandis, 2016). Therefore, when $N_{\text {accumulation }}$ is higher than $N_{\text {Aitken }}$, this indicates long-range transport and a more aged aerosol. $N_{\text {coarse }}$ varied from 3 to $71 \mathrm{~cm}^{-3}$, with a median of $21 \mathrm{~cm}^{-3}$. Coarse mode particles are mostly emitted to the atmosphere from natural sources, e.g., marine aerosol, mineral dust or biological materials.

\subsubsection{Particle classification and origins}

To better understand the particle sources and features, we divided the data from the campaign into different periods. An overview of the classification criteria and features of the different resulting aerosol types are summarized in Table 2. Details about the classification criteria are discussed in the Supplement. Classification results are shown as different background colors in Fig. 4. Note that from 00:00:00 27 September to 00:00:00 28 September, $N_{\text {total }}$ suddenly de- creased. This might due to the wet deposition that happened before the air masses arrived at the measurement site. The precipitation is an output parameter of the calculated NOAA HYSPLIT backward trajectories. From 00:00:00 27 September to 00:00:00 28 September, the total precipitation (sum of precipitation of 144 segment endpoints) exceeded a value of $7 \mathrm{~mm}$ in the past $144 \mathrm{~h}$ (corresponding to $6 \mathrm{~d}$ ) of each backward trajectory history. Therefore, this period was not included in the aerosol classification.

Figure 5 shows the median of PNSDs of the four different aerosol types, with a linear (top) and a logarithmic (bottom) scaling on the $y$ axis. The error bar indicates the range between 25 th and 75 th percentiles. PNSDs which have $N_{\text {Aitken }}$ larger than $N_{\text {accumulation }}$ and $N_{\text {coarse }}<25 \mathrm{~cm}^{-3}$ are attributed to the "marine type" in this work. PNSDs resembling those show three modes, i.e., Aitken, accumulation and coarse modes, which can be clearly distinguished, as shown in blue lines in Fig. 5. For the separation of this marine type, trajectories were additionally examined. The marine type featured the lowest $N_{\text {Aitken }}, N_{\text {accumulation }}$ and $N_{\text {coarse }}$ median values of 189,143 and $7 \mathrm{~cm}^{-3}$, respectively. The minimum between the Aitken and accumulation mode of PNSDs (Hoppel minimum; see Hoppel et al., 1986) at roughly $70 \mathrm{~nm}$ indicates the sizes above which particles had previously been activated to cloud droplets during the history of the air mass at least once. When passing through a cloud, soluble material is added to the activated particles by aqueous-phase chemistry, increasing particulate mass and hence the size of those particles. The coarse mode particles can also be assumed to be sea spray aerosol (SSA) during the marine type period, 


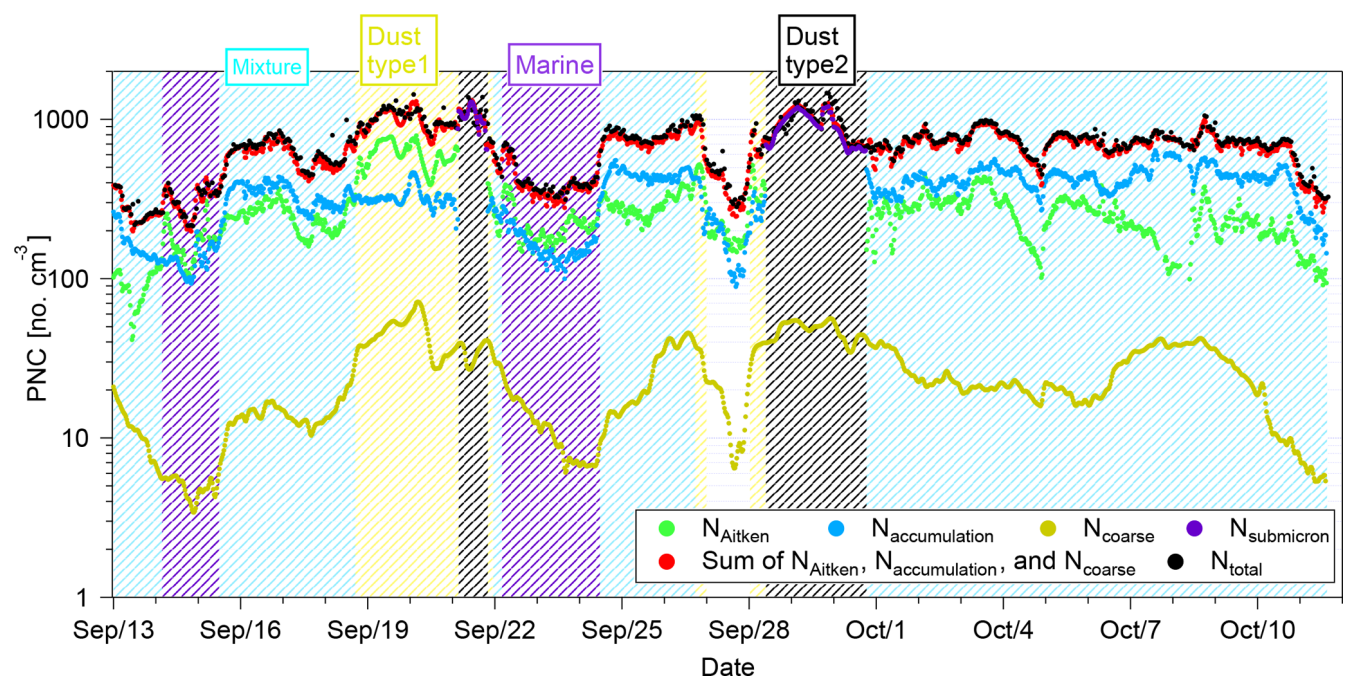

Figure 4. Time series of $N_{\text {Aitken }}, N_{\text {accumulation, }}, N_{\text {coarse }}, N_{\text {submicron }}$, sum of $N_{i}$ and $N_{\text {total }}$ at CVAO. The different shading colors indicate different aerosol type periods.

Table 2. Classification criteria and features of four different particle types.

\begin{tabular}{|c|c|c|c|c|c|c|c|}
\hline \multirow{2}{*}{$\begin{array}{l}\text { Aerosol } \\
\text { type }\end{array}$} & \multirow[t]{2}{*}{ Criteria } & \multicolumn{6}{|c|}{ Features } \\
\hline & & $\begin{array}{c}N_{1}\left(\mathrm{~cm}^{-3}\right) \\
\text { median } \pm \mathrm{SD}^{*}\end{array}$ & $\begin{array}{c}N_{2}\left(\mathrm{~cm}^{-3}\right) \\
\text { median } \pm \mathrm{SD}\end{array}$ & $\begin{array}{c}N_{3}\left(\mathrm{~cm}^{-3}\right) \\
\text { median } \pm \text { SD }\end{array}$ & $\begin{array}{l}N_{\text {total }}\left(\mathrm{cm}^{-3}\right) \\
\text { median } \pm \mathrm{SD}\end{array}$ & $\begin{array}{c}N_{\mathrm{CCN}, 0.30 \%}\left(\mathrm{~cm}^{-3}\right) \\
\text { median } \pm \mathrm{SD}\end{array}$ & Shape of PNSD \\
\hline Marine & $\begin{array}{l}N_{\text {Aitken }}>N_{\text {accumulation }} \\
N_{\text {coarse }}<25 \mathrm{~cm}^{-3}\end{array}$ & $189 \pm 58$ & $143 \pm 41$ & $7 \pm 6$ & $369 \pm 124$ & $190 \pm 49$ & $\begin{array}{l}\text { visible Hoppel minimum } \\
\text { at } 70 \mathrm{~nm}\end{array}$ \\
\hline Mixture & $N_{\text {Aitken }}<N_{\text {accumulation }}$ & $247 \pm 78$ & $405 \pm 102$ & $20 \pm 10$ & $725 \pm 173$ & $478 \pm 76$ & $\begin{array}{l}\text { visible Hoppel minimum } \\
\text { at } 80 \mathrm{~nm}\end{array}$ \\
\hline Dust type1 & $\begin{array}{l}N_{\text {Aitken }}>N_{\text {accumulation }} \\
N_{\text {coarse }}>25 \mathrm{~cm}^{-3}\end{array}$ & $556 \pm 134$ & $312 \pm 50$ & $39 \pm 11$ & $952 \pm 173$ & $332 \pm 44$ & $\begin{array}{l}\text { visible Hoppel minimum } \\
\text { at } 100 \mathrm{~nm}\end{array}$ \\
\hline Dust type2 & $\begin{array}{l}\text { Single mode in submicron } \\
N_{\text {coarse }}>25 \mathrm{~cm}^{-3}\end{array}$ & - & - & $44 \pm 8$ & $994 \pm 218$ & $503 \pm 105$ & no visible Hoppel minimum \\
\hline
\end{tabular}

* 1 standard deviation

as discussed in previous studies (Modini et al., 2015; Wex et al., 2016). A decent correlation $\left(R^{2}=0.69, p<0.01\right)$ was found between SSA number concentration and wind speed (Supplement, Fig. S6). Modini et al. (2015) also observed that SSA number concentration correlated with local wind speed, which is consistent with the fact that SSAs are generated from the process associated with the agitation of the sea surface by air moving above it. The SSA accounted for $1.1 \%$ to $4.4 \%$ of $N_{\text {total }}$ at CVAO (wind speed from 4 to $10 \mathrm{~m} \mathrm{~s}^{-1}$ ), which is relatively low when comparing to Wex et al. (2016), who found the SSA particles contributed $4 \%$ to $10 \%$ of $N_{\text {total }}$ (wind speed up to $14 \mathrm{~m} \mathrm{~s}^{-1}$ ) for the marine aerosol on Barbados. Figure 6 shows the $6 \mathrm{~d}$ backward trajectories with $1 \mathrm{~h}$ time resolution ending at $200 \mathrm{~m}$ above CVAO. Looking at Fig. 6a, which displays the marine periods, the backward trajectories clearly featured paths over the Atlantic Ocean and traveled to Cabo Verde. None of the backward trajectories touched the European or African continents.
PNSDs that have a larger $N_{\text {accumulation }}$ than $N_{\text {Aitken }}$ are attributed to the "mixture type" in this work, shown as green lines in Fig. 5, with three modes, i.e., Aitken, accumulation and coarse modes, which can be clearly distinguished. $N_{\text {Aitken }}, N_{\text {accumulation }}$ and $N_{\text {coarse }}$ have median values of 247 , 405 and $20 \mathrm{~cm}^{-3}$, respectively. The Hoppel minimum of the mixture type is at roughly $80 \mathrm{~nm}$. The respective backward trajectories, colored in green in Fig. 6b, showed that the related air mass came from the north Atlantic Ocean and spent some days over southern Europe and northern Africa. Anthropogenic aerosol and mineral dust may be incorporated into air parcels and transported to Cabo Verde, causing higher levels of Aitken, accumulation and coarse mode particles than in the marine type.

PNSDs with larger $N_{\text {Aitken }}$ than $N_{\text {accumulation }}$ and $N_{\text {coarse }}>$ $25 \mathrm{~cm}^{-3}$ are attributed to the "dust type1" in this work, shown as red lines in Fig. 5. PNSDs attributed to this type show three modes, i.e., Aitken, accumulation and coarse modes, which can be clearly distinguished. $N_{\text {Aitken, }}$ 

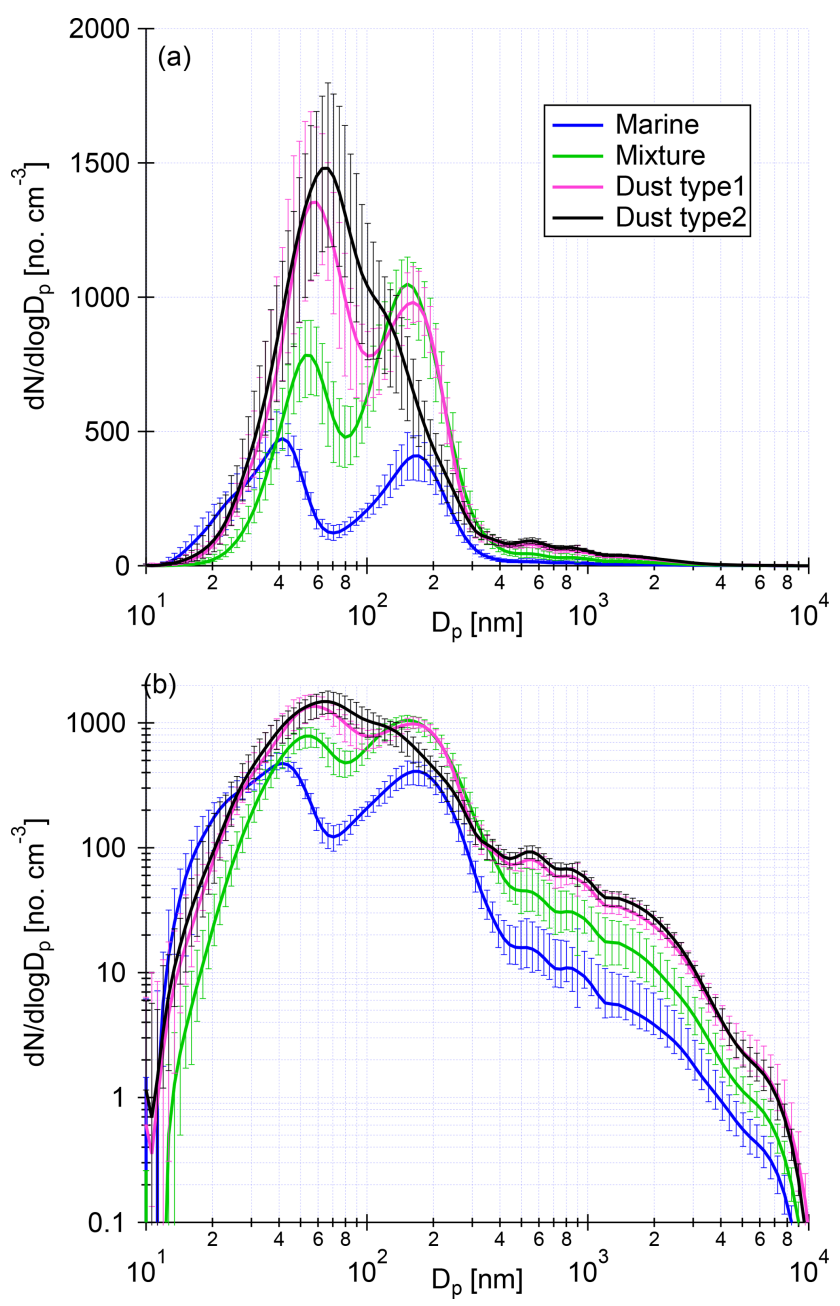

Figure 5. The median of PNSDs of marine type (blue), mixture type (green), dust type1 (purple) and dust type2 (black), with a linear (a) and a logarithmic (b) scaling on the $y$ axis. The error bar indicates the range between 25 th and 75 th percentiles.

$N_{\text {accumulation }}$ and $N_{\text {coarse }}$ had median values of 556,312 and $39 \mathrm{~cm}^{-3}$, respectively. The Hoppel minimum of the mixture type is at roughly $100 \mathrm{~nm}$. The respective backward trajectories, colored in red in Fig. 6c, featured two pathways. One air mass group originated from the north Atlantic Ocean and stayed a few days over southern Europe and northern Africa. Another air mass group came from the Sahara.

It is interesting to note that the Hoppel minimum is at the lowest diameter for the marine air mass $(\sim 70 \mathrm{~nm})$, compared to all other air masses. This suggests that the supersaturation in the clouds forming in the clean marine air masses is highest, as there is less surface area for the water vapor to condense onto during cloud formation.

PNSDs which featured a single mode in the submicron size range are attributed to "dust type2", shown as black lines in Fig. 5. No visible Hoppel minimum can be seen. The dust type2 featured highest $N_{\text {total }}$ and $N_{\text {coarse }}$ median values of 994 and $44 \mathrm{~cm}^{-3}$, respectively. It is worth mentioning that previous field measurements at the Sahara found similar PNSDs to what we observed in this study (Kaaden et al., 2009; Kandler et al., 2009; Weinzierl et al., 2009). We assumed that dust type 2 is the heaviest dust plume period during this campaign. The respective backward trajectories, colored in black in Fig. 6d, showed that related air masses originated from the Sahara.

The higher $N_{\text {coarse }}$ during dust type 1 and type 2 periods is due to the direct dust aerosol from the Sahara. Schladitz et al. (2011b) also found that the higher coarse mode number concentration at Cabo Verde originated from the Sahara. Besides, a very high concentration of Aitken mode particles was observed during dust type 1 and dust type 2 periods. A previous study also found that an African-influenced period showed a great enhancement in the Aitken mode particles and an overall increase in the number of particles of all sizes (Allan et al., 2009). Nie et al. (2014) found that new particle formation and growth happened in the remote ambient atmosphere during the strongest observed dust episodes. Both the formation and growth rates of particles in the diameter range of $15-50 \mathrm{~nm}$ were enhanced during the dust episodes. In our data, we found that backward trajectories often traveled from the upper troposphere down to the marine boundary layer during dust periods, which means that Aitken mode particles could have been transported from the upper troposphere. Therefore, there are different factors contributing to the observed high $N_{\text {Aitken }}$ and $N_{\text {accumulation }}$ during dust plumes, such as direct transport of particles from the desert and Sahel region, and additional new particle formation and growth in the vicinity or in the upper troposphere.

To summarize Sect. 3.2, based on number concentrations in different aerosol modes, an aerosol classification was done, and four well-separable types of PNSDs were found, i.e., the marine type, mixture type, dust type1 and dust type2. Marine type particles are mainly from the Atlantic Ocean, while dust type particles are mainly from the Sahara. Mixture type particles are a combination of marine, anthropogenic and dust particles. Backward trajectories support this classification and analysis. The marine, mixture, dust type 1 and dust type 2 in this study are comparable to type A, D, C and B in Fomba et al. (2014), respectively, who characterized particle chemical composition at CVAO over a time period of 4 years.

\subsection{Comparison of CVAO and MV}

In this section, we will compare the PNC, PNSDs and $N_{\mathrm{CCN}}$ at CVAO and MV. Cloud events are identified based on the difference in integrated PNC between MV and CVAO. Cloud effects on PNSDs and $N_{\mathrm{CCN}}$ will also be discussed. 

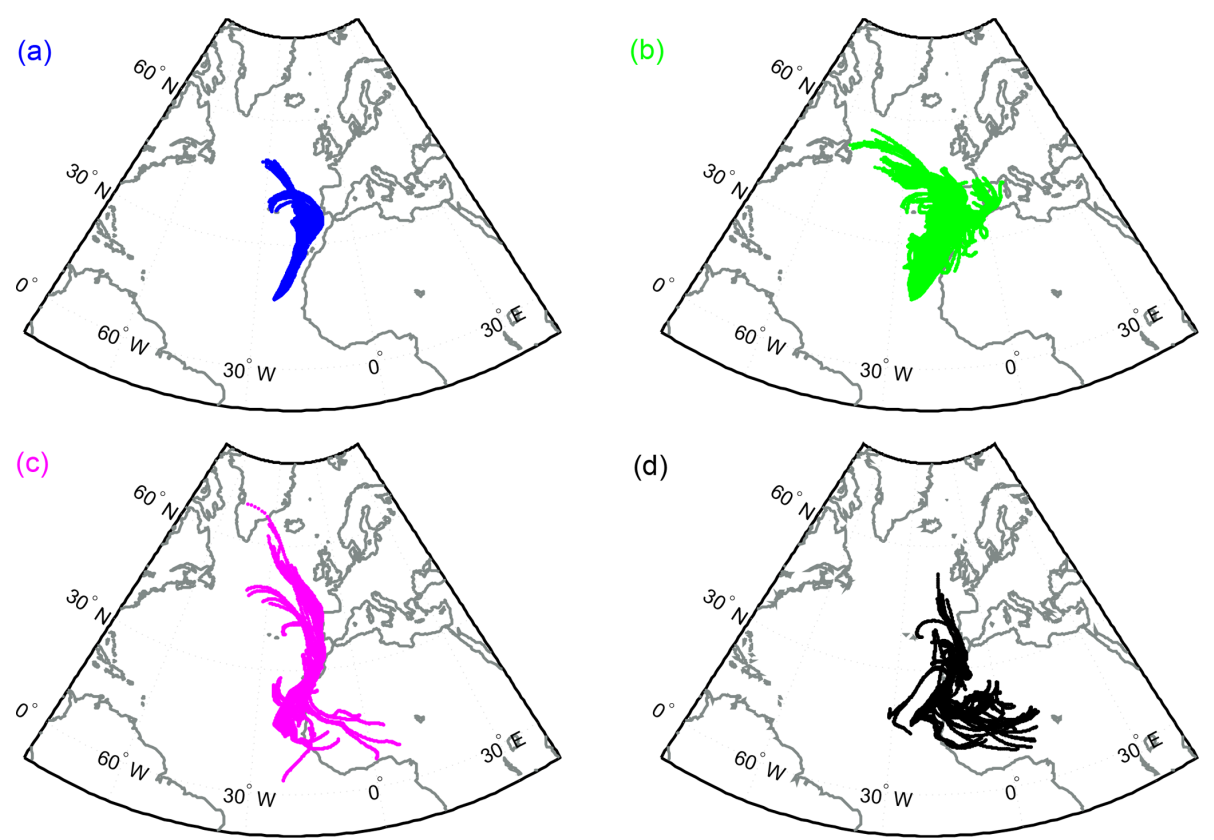

Figure 6. The $6 \mathrm{~d}$ backward trajectories arriving at CVAO at a height of $200 \mathrm{~m}$ with $1 \mathrm{~h}$ resolution for marine type (a), mixture type (b), dust type1 (c) and dust type2 (d). Each calculation is shown as a separate dot, which is separately visible when air masses moved fast.

\subsubsection{Comparison of PNC and PNSD}

PNSDs from 10 to $800 \mathrm{~nm}$ were measured by MPSS and a bimodal lognormal parameterization was adopted to calculate $N_{\text {Aitken }}$ and $N_{\text {accumulation }}$ at MV. Figure 7 shows the time series of PNC in the size range between 10 and $800 \mathrm{~nm}$ at CVAO $\left(N_{10-800 \mathrm{~nm}}^{\mathrm{CVAO}}\right)$ and $\mathrm{MV}\left(N_{10-800 \mathrm{~mm}}^{\mathrm{MV}}\right)$ in Fig. $7 \mathrm{a}$, PNC of accumulation mode at $\mathrm{CVAO}\left(N_{\text {accumulation }}\right)$ and $\mathrm{MV}$ $\left(N_{\text {accumulation }}^{\mathrm{MV}}\right)$ in Fig. 7b, and PNC of Aitken mode at CVAO $\left(N_{\text {Aitken }}^{C C A O}\right)$ and $\mathrm{MV}\left(N_{\text {Aitken }}^{\mathrm{MV}}\right)$ in Fig. 7c. The variation in $N_{10-800 \mathrm{~nm}}^{\mathrm{CVAO}}$ and $N_{10-800 \mathrm{~nm}}^{\mathrm{MV}}$ was similar sometimes, e.g., from 23 to 25 September. However, sometimes the concentrations at MV were obviously lower than the respective values at CVAO, at least for $N_{10-800 \mathrm{~nm}}^{\mathrm{MV}}$ and $N_{\text {accumulation}}^{\mathrm{MV}}$, as, for example, from 5 to 9 October. Such a decrease was sometimes, but not always, also observed for $N_{\text {Aitken }}^{\mathrm{MV}}$. This is a typical observation for cloudy air, in which particles from the accumulation mode and maybe also some from the Aitken mode are activated to cloud droplets which are then removed in the aerosol inlet on MV. When the ratio of $N_{\text {accumulation }}^{\mathrm{MV}}$ to $N_{\text {accumulation }}^{\mathrm{CVAO}}$ was lower than 0.85 , we assumed that $\mathrm{MV}$ is in the cloud. When the trimodal fitting function did not work for the CVAO data set (from 03:30 to 20:00 21 September and from 09:30 28 September to 18:30 30 September), a slightly different approach was needed. For that, we used the ratio of PNC in the size range between 80 and $800 \mathrm{~nm}$ at $\mathrm{MV}\left(N_{80-800 \mathrm{~nm}}^{\mathrm{MV}}\right)$ to that at CVAO $\left(N_{80-800 \mathrm{~nm}}^{\mathrm{CVAO}}\right)$ (replacing the ratio of $N_{\text {accumulation }}^{\mathrm{M}}$ to $\left.N_{\text {accumulation }}^{\mathrm{CVAO}}\right)$. When this ratio was lower than 0.75 , we assumed that MV is in the cloud. It is described in more detail in the Supplement how this ratio was derived separately for cases with trimodal and bimodal fitting. The time for cloud events is shown as red shading in Fig. 7. As outlined above in the meteorology part, we observed RH $=100 \%$ at MV. Figure S8 shows the time series of RH at MV together with the time for cloud events as red shading. It is clear that times with $\mathrm{RH}=100 \%$ are consistent with cloud events identified as described above, which verifies our identification of cloud events.

To better understand the cloud effect of PNSDs, we compared the PNSDs at CVAO and MV during cloud events and noncloud events of different aerosol types. Figure 8 shows the median PNSDs of different particle types during cloud events and noncloud events. During noncloud events, PNSDs at CVAO ( $\mathrm{PNSD}_{\text {non-cloud }}^{\mathrm{CVAO}}$ ) and MV (PNSD $\mathrm{MV}$-cloud $)$ were similar for marine, mixture or dust type 1 periods. During dust type2, there is only a very short period of noncloud event with 15 PNSDs observed. Therefore, we did not include the comparison of $\mathrm{PNSD}_{\text {non-cloud }}^{\mathrm{CVAO}}$ and $\mathrm{PNSD}_{\text {non-cloud }}^{\mathrm{MV}}$ during the dust type2 2 period in Fig. 8.

During noncloud events, PNSDs at CVAO and MV were the same, as shown in Fig. 8. For periods with clouds, PNSDs in the size range $>80 \mathrm{~nm}$ at $\mathrm{MV}$ are lower than that at CVAO for all the particle types. For dust type 1 and dust type2, depending on the clouds, i.e., the highest supersaturation the particles encounter, particles in Aitken mode were also activated to cloud droplets. For particles in the size range < $40 \mathrm{~nm}$, PNSDs are similar during cloud and noncloud events. This is because the particle size is not large enough to activate to cloud droplets. Furthermore, it also indicates that PNSDs are similar at CVAO and MV during cloud events, at least in 


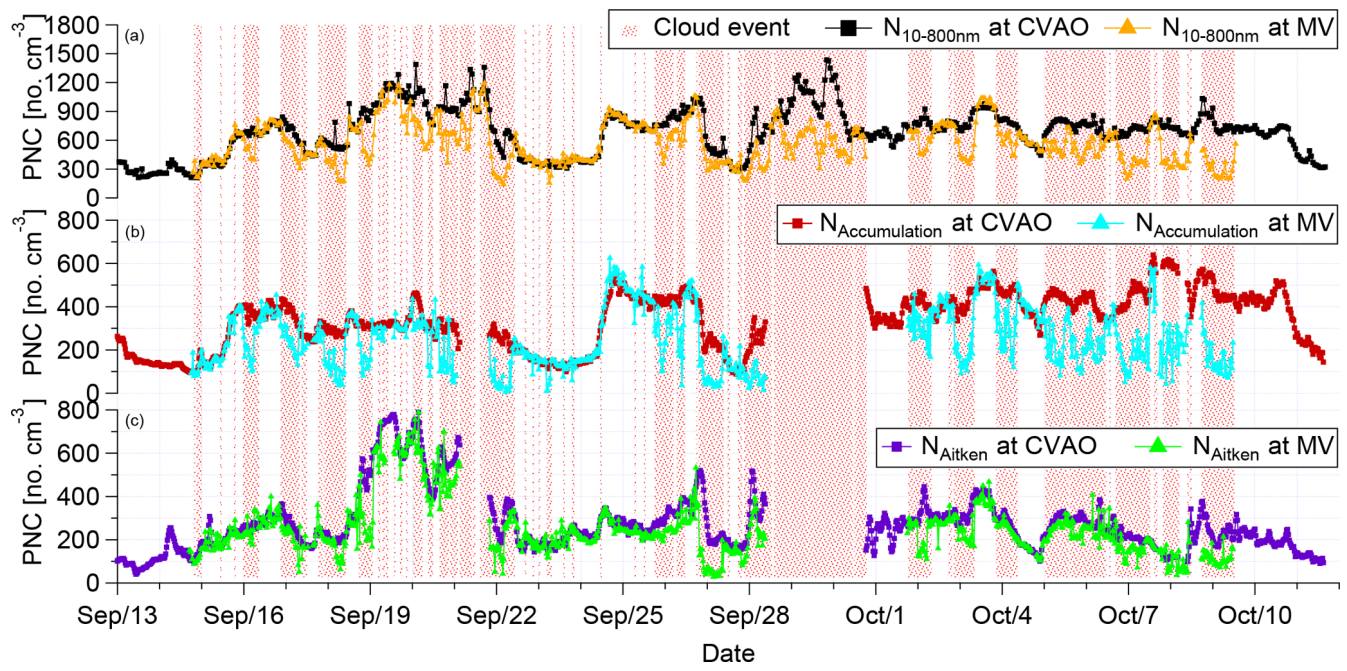

Figure 7. Time series of $N_{10-800 \mathrm{~nm}}^{\mathrm{CVAO}}$ and $N_{10-800 \mathrm{~nm}}^{\mathrm{MV}}$ in panel (a), $N_{\text {Aitken }}^{\mathrm{CVAO}}$ and $N_{\text {Aitken }}^{\mathrm{MV}}$ in the panel (b), and $N_{\text {accumulation }}^{\mathrm{CVAO}}$ and $N_{\text {accumulation }}^{\mathrm{MV}}$ in panel (c). The times of cloud events are shown by red shading.

the size range $<40 \mathrm{~nm}$. For a more detailed comparison of PNSDs at CVAO and MV, contour plots for PNSDs can be found in Fig. S9 in the Supplement.

During the campaign, a decoupled marine boundary layer was observed with our balloon measurements in three cases, i.e., 10:30 to 11:00 16 September, 16:00 to 16:30 5 October and 17:20 to 17:50 12 October (shown as red dots in Fig. 1). Only for the first decoupling case (10:30 to 11:00 16 September) was MV cloud free; otherwise, PNSDs were similar at CVAO and MV (Fig. S10). Therefore, the MBL may be generally well mixed, maybe still from times before the decoupling of the layers formed. On the other hand, lifting of the air masses over the mountain might also partially explain this observation. However, due to the fact that there is only this one decoupled case, a thorough analysis of the influence of coupling and decoupling can not be done.

\subsubsection{Comparison of $N_{\mathrm{CCN}}$}

Figure 9 shows the scatter plot of $N_{\mathrm{CCN}}$ at $\mathrm{CVAO}\left(N_{\mathrm{CCN}}^{\mathrm{CVAO}}\right)$ against that at $\mathrm{MV}\left(N_{\mathrm{CCN}}^{\mathrm{MV}}\right)$ during cloud events (green dots) and noncloud events (red rectangles) at different supersaturations. During cloud events, large particles that had been activated to cloud droplets were removed by the aerosol inlet on MV. Therefore, $N_{\mathrm{CCN} \text {,cloud }}^{\mathrm{CVAO}}$ is larger than $N_{\mathrm{CCN} \text {,cloud }}^{\mathrm{MV}}$ at each supersaturation. During noncloud events, all the data points are close to the $1: 1$ line (for the slopes see Fig. 9), and $R^{2}$ values between $N_{\mathrm{CCN} \text {,non-cloud }}^{\mathrm{CVAO}}$ and $N_{\mathrm{CCN} \text {,non-cloud }}^{\mathrm{MV}}$ are all above 0.90 , indicating $N_{\mathrm{CCN}}$ is similar at CVAO and MV. Although there were slight differences in supersaturation at CVAO and MV due to the CCNC calibration, the similarity between $N_{\mathrm{CCN}}$ at the two stations conveys the same message as what was discussed before concerning the comparison of
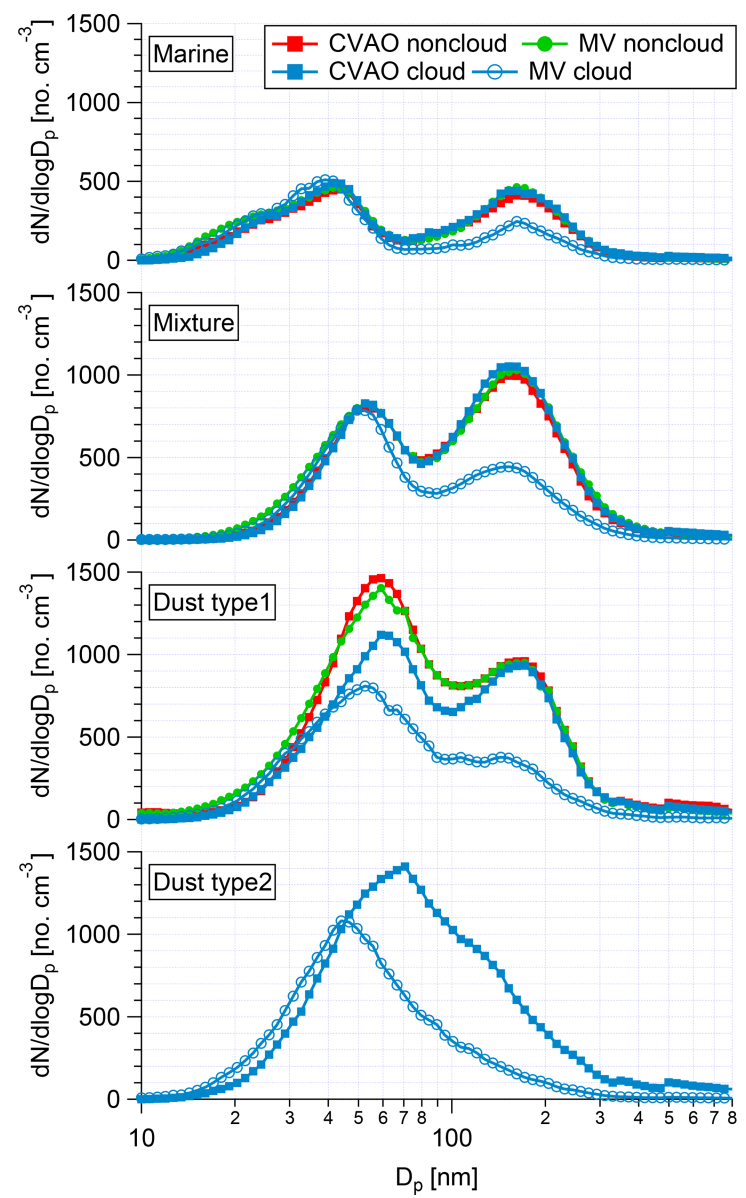

Figure 8. The median of PNSDs for four different particle types during cloud events and noncloud events at CVAO and MV. 

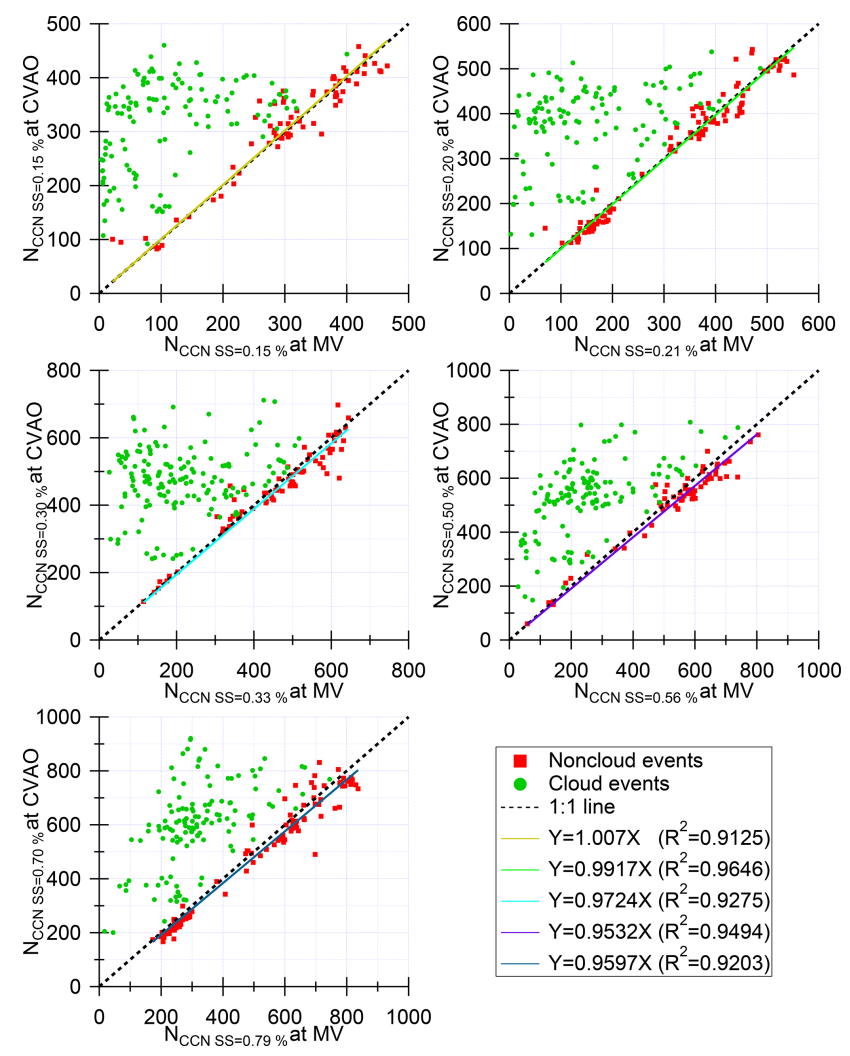

Figure 9. Scatter plots of $N_{\mathrm{CCN}}$ at CVAO against those at $\mathrm{MV}$ at different supersaturations. Slope and $R^{2}$ values for these fits are given in the legend.

PNSDs at CVAO and MV, i.e., particles are generally well mixed in the MBL.

To summarize Sect. 3.3, cloud events were observed at MV and can be identified based on the integrated concentrations between ground and cloud level. During the cloud events, larger particles (mainly accumulation and coarse mode) are activated to cloud droplets. Aitken mode particles starting with sizes of roughly $40 \mathrm{~nm}$ can also be activated to cloud droplets if the cloud is strong enough. During noncloud events, PNC, PNSD and $N_{\mathrm{CCN}}$ are similar at CVAO and MV. The aerosol particles measured at ground level (CVAO) can represent the aerosol particles at the cloud level (MV).

\subsection{Particle hygroscopicity}

In this section, we will focus on $N_{\mathrm{CCN}}, d_{\text {crit }}$ and $\kappa$ measurements at CVAO. As outlined above, PNSDs and $N_{\mathrm{CCN}}$ measured at ground level are similar to those at cloud level. Therefore, measurements at CVAO can be representative of that at MV. Firstly, a thorough statistical analysis of $N_{\mathrm{CCN}}$, $d_{\text {crit }}$ and $\kappa$ will be discussed. Secondly, the marine and dust aerosol contributions of particles to $N_{\mathrm{CCN}}$ and their $\kappa$ values will be compared.

\subsubsection{Statistical analysis of $N_{\mathrm{CCN}}, d_{\text {crit }}$ and $\kappa$}

Figure 10a shows the time series of $N_{\text {total }}$ and $N_{\mathrm{CCN}}, d_{\text {crit }}$ in Fig. 10b and $\kappa$ in Fig. 10c, with different colors for different supersaturations. The error bars of $d_{\text {crit }}$ show 1 standard deviation (SD), and error bars of $\kappa$ show 1 geometric standard deviation (geoSD). Explanation of error bars can be found in Sect. 2.4 as well as in the Supplement. $N_{\mathrm{CCN}}$ shows large variability, e.g., $N_{\mathrm{CCN}, 0.30 \%}$ varied from 106 to $884 \mathrm{~cm}^{-3}$, with a median of $509 \mathrm{~cm}^{-3}$. We observed highest $N_{\mathrm{CCN}, 0.30 \%}$ of $503 \mathrm{~cm}^{-3}$ (median) during dust type 2 periods, and lowest $N_{\mathrm{CCN}, 0.30 \%}$ of $109 \mathrm{~cm}^{-3}$ (median) during

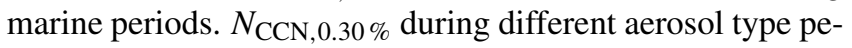
riods are summarized in Table 2. Figure 11a shows the boxplot of $N_{\mathrm{CCN}}$ at different supersaturations during the whole campaign. As can be seen, $N_{\mathrm{CCN}}$ increases towards higher supersaturation, which is expected. The median of $N_{\mathrm{CCN}}$ at different supersaturations also exhibited large variability, varying from 327 (median) at a supersaturation of $0.15 \%$ to $652 \mathrm{~cm}^{-3}$ (median) at a supersaturation of $0.70 \%$. Table 3 summarizes those numbers and shows additional details.

$d_{\text {crit }}$ at supersaturations of $0.15 \%, 0.20 \%, 0.50 \%$ and $0.70 \%$ were almost constant throughout the campaign, as shown in Fig. 10b. The mean value of $d_{\text {crit }}$ and its SD are summarized in Table 3. For the supersaturations of $0.70 \%$ and $0.50 \%, d_{\text {crit }}$ is below $80 \mathrm{~nm}$, i.e., inside the Aitken mode. However, for the lower supersaturations of $0.15 \%$ and $0.20 \%, d_{\text {crit }}$ is located in the accumulation mode. Consequently, hygroscopicities derived at these supersaturations can be assumed to be representative of the Aitken (at supersaturations of $0.70 \%$ and $0.50 \%$ ) and the accumulation modes (at supersaturation of $0.10 \%$ and $0.20 \%$ ), respectively. $d_{\text {crit }}$ at a supersaturation of $0.30 \%\left(d_{\text {crit }, 0.30 \%}\right)$ is not as constant as it is at other supersaturations, and it is larger during the marine type period than during other periods. With a median of $79.7 \mathrm{~nm}$, it is close to the Hoppel minimum. Therefore, the hygroscopicity derived at a supersaturation of $0.30 \%$ can be assumed to be representative of the mixture of Aitken and accumulation particles.

The particle hygroscopicity, expressed as $\kappa$, can be seen as a measure for average particle chemical composition. $\kappa$ values at different supersaturations show little variability over time (lower panel in Fig. 10), with geoSD lower than 0.12, i.e., there is no clear trend in $\kappa$ over time during the campaign. A slightly increasing trend of $\kappa$ was observed with decreasing supersaturations, as shown in Fig. 11c. At supersaturations of $0.70 \%$ and $0.50 \%$, i.e., for Aitken mode particles, $\kappa$ values are 0.18 and 0.25 (geomean), respectively. At the lowest supersaturation of $0.15 \%$ and $0.20 \%$, i.e., for accumulation mode particles, $\kappa$ values are 0.32 and 0.34 (geomean). Table 3 summarizes those numbers and shows additional details.

Figure 11d shows $\kappa$ as a function of $d_{\text {crit }}$ and error bars of $\kappa$ and $d_{\text {crit }}$ show geoSD and SD, respectively. A slightly increasing trend of $\kappa$ over increasing $d_{\text {crit }}$ is observed. It 


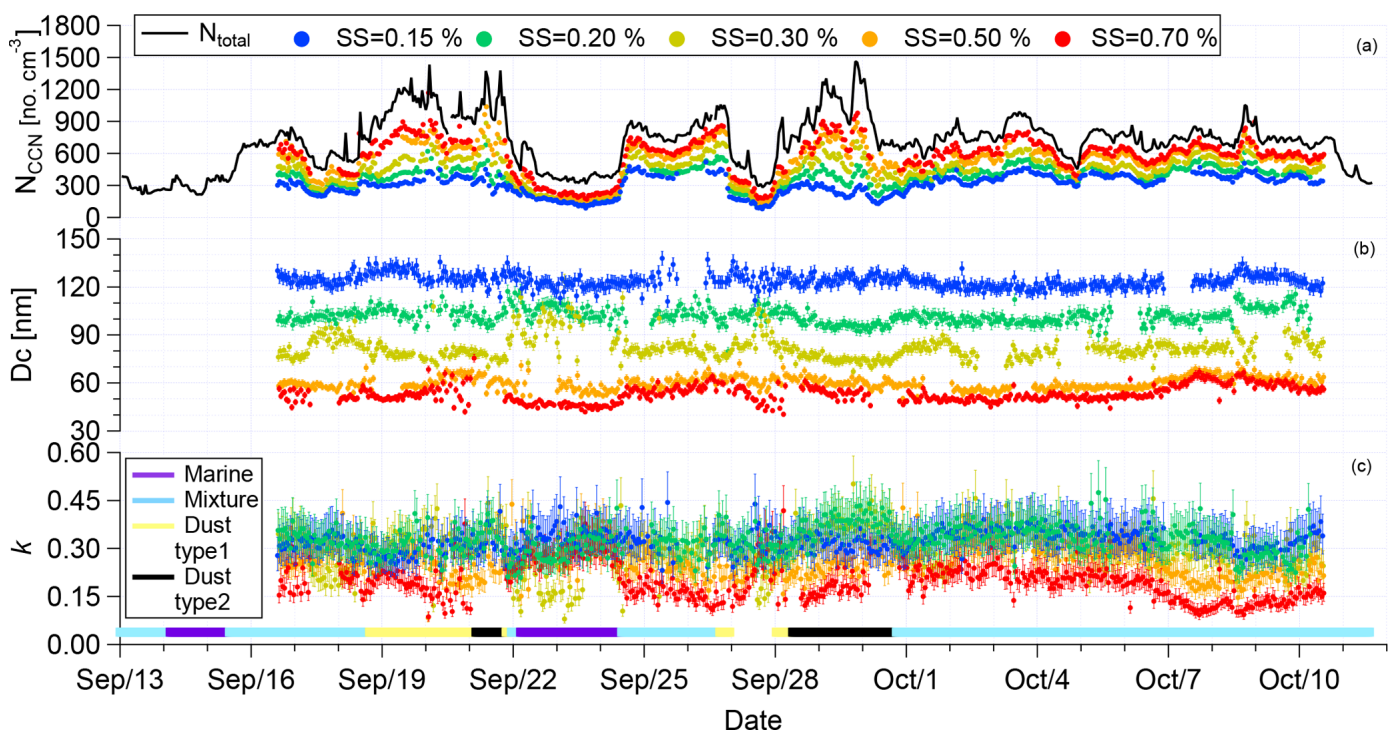

Figure 10. Time series of $N_{\mathrm{CCN}}$ in (a), $d_{\text {crit }}$ in (b) and $\kappa$ in (c). All of those are measured at CVAO. Error bars of $d_{\text {crit }}$ and $\kappa$ show 1 standard deviation and 1 geometric standard deviation. The color bar in (c) indicates the times of different aerosol type periods.

Table 3. Median and mean values of $N_{\mathrm{CCN}}, d_{\text {crit }}, \kappa, 1$ standard deviation of $d_{\text {crit }}$ and 1 geometric standard deviation of $\kappa$ at different supersaturations.

\begin{tabular}{lrrrr}
\hline & Supersaturation $(\%)$ & $\begin{array}{r}N_{\mathrm{CCN}}\left(\mathrm{cm}^{-3}\right) \\
\text { median, mean } \pm \mathrm{SD}\end{array}$ & $\begin{array}{r}d_{\text {crit }}(\mathrm{nm}) \\
\text { mean } \pm \mathrm{SD}\end{array}$ & $\begin{array}{r}\kappa \\
\text { geomean, }+ \text { geoSD, }-\mathrm{geoSD}^{*}\end{array}$ \\
\hline Whole campaign & 0.15 & $327,320 \pm 88$ & $123.8 \pm 8.9$ & $0.32,0.09,0.07$ \\
& 0.20 & $414,400 \pm 112$ & $100.4 \pm 7.7$ & $0.34,0.10,0.08$ \\
& 0.30 & $509,495 \pm 143$ & $79.7 \pm 8.4$ & $0.30,0.12,0.08$ \\
& 0.50 & $602,593 \pm 176$ & $59.8 \pm 6.9$ & $0.25,0.09,0.07$ \\
& 0.70 & $652,638 \pm 186$ & $53.3 \pm 6.5$ & $0.18,0.08,0.06$ \\
\hline Marine & 0.15 & $146,155 \pm 37$ & $121.2 \pm 5.0$ & $0.34,0.08,0.06$ \\
& 0.20 & $166,177 \pm 43$ & $103.5 \pm 7.8$ & $0.31,0.10,0.08$ \\
& 0.30 & $190,202 \pm 49$ & $87.8 \pm 15.7$ & $0.23,0.17,0.10$ \\
& 0.50 & $191,215 \pm 70$ & $56.9 \pm 5.7$ & $0.30,0.12,0.09$ \\
Dust type2 & 0.70 & $235,260 \pm 72$ & $46.1 \pm 2.2$ & $0.28,0.06,0.05$ \\
\hline 0.15 & $259,242 \pm 56$ & $124.6 \pm 4.7$ & $0.32,0.07,0.06$ \\
& 0.20 & $370,357 \pm 77$ & $96.9 \pm 4.2$ & $0.37,0.08,0.07$ \\
& 0.30 & $503,501 \pm 105$ & $74.9 \pm 3.6$ & $0.36,0.08,0.06$ \\
& 0.50 & $654,636 \pm 125$ & $60.4 \pm 3.2$ & $0.25,0.06,0.05$ \\
& 0.70 & $798,764 \pm 111$ & $52.6 \pm 5.5$ & $0.19,0.08,0.06$ \\
\hline
\end{tabular}

* 1 geometric standard deviation

suggests that the soluble, likely inorganic, material added during cloud processing increases $\kappa$ of the originally very organic-rich particles, which has also been observed in previous studies (Kalivitis et al., 2015; Kristensen et al., 2016). Overall, $\kappa$ averaged 0.28. Pringle et al. (2010) used an atmospheric chemistry model to derive global distributions of effective particle hygroscopicity $\kappa$. For CVAO, this model resolved an annual cycle of monthly-mean $\kappa$ values ranging from 0.25 in February to 0.60 in April. This annual circle of $\kappa$ likely originated in a change of chemical composition of the aerosol throughout the year, related to different precursors and a higher organic content during times with higher algal activity. For September and October, the period of this study, values of 0.35 and 0.30 were reported, respectively, which is consistent with what we obtained during this campaign.

The Hoppel minimum diameter range of 70 to $100 \mathrm{~nm}$ for different aerosol types (mentioned in Sect. 3.2.2), together with the average $\kappa$ of 0.28 , can be used to obtain a rough estimate of maximum supersaturations present in trade wind clouds along the path of the sampled air masses. Resulting 

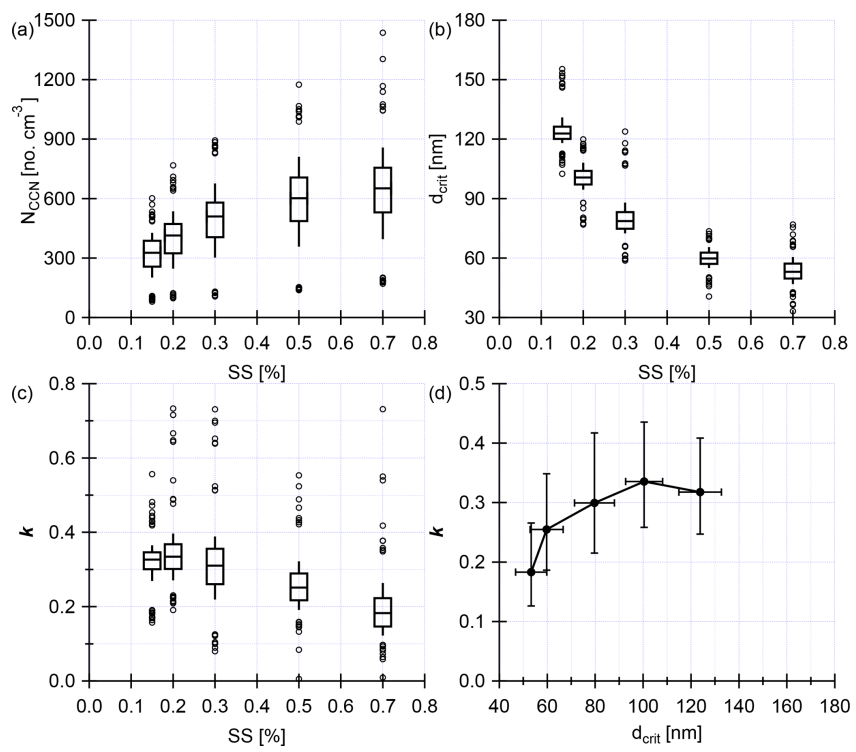

Figure 11. Boxplots of $N_{\mathrm{CCN}}(\mathbf{a}), d_{\text {crit }}$ (b) and $\kappa$ (c) at different supersaturations (SS). Whiskers show the 10th to 90th percentiles. Circles show the outliers $(1 \%)$. (d) $\kappa$ as a function of $d_{\text {crit }}$. Error bars of $d_{\text {crit }}$ and $\kappa$ show 1 standard deviation and 1 geometric standard deviation, respectively.

values are roughly $0.22 \%$ to $0.37 \%$ for dust type 2 and marine air masses, respectively. These are close to an earlier estimate given in Clarke et al. (1996) of $0.35 \%$, and they can be interpreted as typical values for trade wind cumuli.

\subsubsection{Dust and marine comparison}

In this section, we will focus on examining the difference between the cleanest periods (marine type) and heaviest observed dust pollution periods (dust type2). Therefore, we compared $N_{\mathrm{CCN}}$ and $\kappa$ during marine type and dust type 2 periods. Figure $12 \mathrm{a}$ shows the boxplot of $N_{\mathrm{CCN}}$ as a function of supersaturation. As outlined above, during dust periods, the aerosol shows a great enhancement in the Aitken, accumulation and coarse mode particles; therefore, overall $N_{\mathrm{CCN}}$ increases at different supersaturations. It is clear that $N_{\mathrm{CCN}}$ during dust type 2 periods is much higher than that during marine periods. For example, $N_{\mathrm{CCN}, 0.30 \%}$ median values were 503 and $190 \mathrm{~cm}^{-3}$ during dust type 2 and marine periods, respectively. During marine periods, $N_{\text {coarse, }}$ i.e., SSA particles, accounted for roughly $3.7 \%$ of $N_{\mathrm{CCN}, 0.30 \%}$, for the range of wind speeds from 4 to $10 \mathrm{~m} \mathrm{~s}^{-1}$ that were present during this study. This is relatively low compared to Wex et al. (2016), who found that the SSA particles accounted for up to $15 \%$ of $N_{\mathrm{CCN}, 0.30 \%}$ for wind speeds up to $14 \mathrm{~m} \mathrm{~s}^{-1}$ for the marine aerosol on Barbados, and Modini et al. (2015), who found that SSA particles accounted for up to $16 \%$ to $28 \%$ (wind speeds up to $16 \mathrm{~m} \mathrm{~s}^{-1}$ ) and $5 \%$ to $10 \%$ (wind speed from 4 to $10 \mathrm{~m} \mathrm{~s}^{-1}$ ) of $N_{\mathrm{CCN}, 0.30 \%}$. However, these fractions not only depend on the concentrations of SSA but
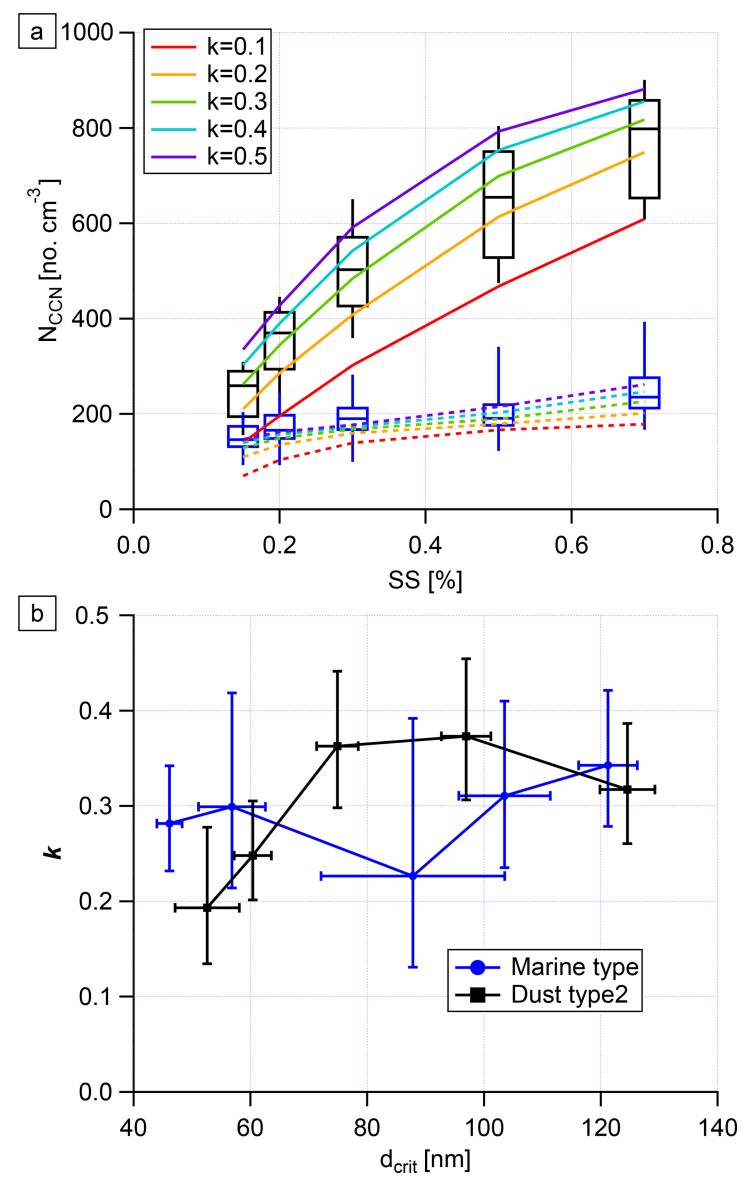

Figure 12. (a) Boxplots of $N_{\mathrm{CCN}}$ as a function of $\kappa$ for marine type (blue) and dust type2 (black). Whiskers show the 10th to 90th percentiles. The predicted $N_{\mathrm{CCN}}$ based on median PNSD and different $\kappa$ values $(0.1,0.2,0.3,0.4$ and 0.5$)$ are shown in solid (during dust type 2 period) and dashed lines (during marine period). (b) $\kappa$ as a function of $d_{\text {crit }}$ for marine type (blue) and dust type2 (black). Error bars of $d_{\text {crit }}$ and $\kappa$ show 1 standard deviation and 1 geometric standard deviation, respectively.

also on those of particles in the accumulation mode, which have other sources. Still, the respective accumulation modes and related particle concentrations in Modini et al. (2015), Wex et al. (2016) and the present study resemble each other. Therefore the lower fractions of SSA particles in our study are likely connected to the low wind speeds (lower SSA number concentration) or, to some extent, to different accumulation mode particle number concentrations.

$\kappa$ as a function of $d_{\text {crit }}$ is shown in Fig. 12b. The error bars of $d_{\text {crit }}$ and $\kappa$ show SD and geoSD, respectively. During dust type2, slightly increasing $\kappa$ with increasing $d_{\text {crit }}$ was observed, similar to the overall trend we described above. $\kappa$ featured lower values from 0.13 to 0.31 for Aitken mode particles, while higher values from 0.26 to 0.45 were found for accumulation mode particles. Until now, the only field measurement of particle hygroscopicity during a dust plume at 
Cabo Verde was carried out by Schladitz et al. (2011a), who found that hygroscopic particles featured a $\kappa$ value (based on hygroscopic growth factor of particles) from 0.35 to 0.65 . Our CCN-derived $\kappa$ values in this study for the aerosol influenced by dust are therefore comparable to the values reported by Schladitz et al. (2011a).

No clear trend of $\kappa$ with $d_{\text {crit }}$ was observed during marine type periods (as shown in Fig. 12), during which $\kappa$ averaged 0.30 . Larger error bars of $\kappa$ and $d_{\text {crit }}$ at the supersaturation of $0.30 \%$ were observed, as in this case the $d_{\text {crit }}$ is close to the Hoppel minimum, where a small change in $N_{\mathrm{CCN}}$ causes a comparably large change in $d_{\text {crit }}$ (explained in the Supplement). Kristensen et al. (2016) found that, for the marine aerosol on Barbados in June and July 2013, values for $\kappa$ of 0.2 to 0.5 were derived, which are consistent with this study. When considering the scatter observed in $\kappa$ (see the error bars in Fig. 12), $\kappa$ during the dust type 2 period still agreed with that of the marine period within uncertainty. Therefore, no distinguishable differences in $\kappa$ during marine and dust periods in the size range from 40 to $140 \mathrm{~nm}$ were found during this campaign.

We additionally derived $N_{\mathrm{CCN}}$ based on PNSDs. For that, we assumed values for $\kappa$ of $0.1,0.2,0.3,0.4$ or 0.5 , and we calculated the corresponding $d_{\text {crit }}$ at different supersaturations. The integrated particle number concentrations in the size range larger than $d_{\text {crit }}$ were derived from the median PNSDs during dust type 2 and marine periods. These particle number concentrations also can be treated as the predicted $N_{\mathrm{CCN}}$ at different supersaturations, as shown in solid (dust type2) and dashed (marine type) lines with different colors (indicating different $\kappa$ ) in Fig. 12a. As expected, the thusly derived $N_{\mathrm{CCN}}$ values were within the measured $N_{\mathrm{CCN}}$ range. Comparing the solid and dashed lines, it can be seen that different aerosol types, i.e., different PNSDs, played an important role in $N_{\mathrm{CCN}}$ variation. When looking at the results from the different $\kappa$ values, we found that the particle chemical composition did not control $N_{\mathrm{CCN}}$, especially when the particle number concentration was very low. These colored solid and dashed lines connected the $\kappa$ and $N_{\mathrm{CCN}}$, which can be helpful for $N_{\mathrm{CCN}}$ predictions in modeling studies.

To summarize Sect. 3.4, overall there is a slight increase in $\kappa$ with particle size, indicating the addition of soluble, likely inorganic, material during cloud processing. $\kappa$ values in this study are comparable to previous model work and field measurements. $N_{\mathrm{CCN}}$ during the heaviest observed dust periods is much higher than that during marine periods, while $\kappa$ values for these two periods show no significant difference.

\section{Conclusions}

The MarParCloud campaign took place in September and October 2017 on Cabo Verde to investigate the aerosols prevailing in the Atlantic Ocean. As the first in a series of publications to come from the MarParCloud campaign, this study provides a thorough characterization of the abundance, properties and sources of aerosol particles in general, and CCN in particular, close to both sea-level and cloud-level heights with measurements done at the Cape Verde Atmospheric Observatory (CVAO) and on the top of Monte Verde (MV), respectively.

$N_{\text {total }}$ varied from $\sim 200$ to $\sim 1500 \mathrm{~cm}^{-3}$, with a median of $\sim 700 \mathrm{~cm}^{-3}$ at CVAO. A trimodal parameterization method was deployed to characterize PNC. Based on number concentrations in different aerosol modes, four wellseparable types of PNSDs were found, i.e., the marine type, mixture type, dust type1 and dust type2. These different aerosol types originate from different regions. The marine type aerosol mainly originates from the Atlantic Ocean, while the dust type aerosol mainly comes from the Saharan region. During marine periods, the coarse mode can be attributed to sea spray aerosol, and the corresponding particle number concentration accounted for about $3.7 \%$ of $N_{\mathrm{CCN}, 0.30 \%}$ and for about $1.1 \%$ to $4.4 \%$ of $N_{\text {total }}$. Because of lower wind speeds that were present at CVAO, this value is lower than previous field measurements (Modini et al., 2015; Wex et al., 2016).

A thorough comparison of PNC, PNSDs and $N_{\mathrm{CCN}}$ at CVAO and MV clearly showed these parameters to be similar at both stations in the absence of clouds. Cloud events were observed at MV during roughly $58 \%$ of the time. During the cloud events, larger particles (mainly accumulation and coarse mode) are activated to cloud droplets and our data suggest that the maximum supersaturation in the clouds is higher the cleaner the air mass gets, leading to a lower Hoppel minimum. Altogether, it was observed that the boundary layer is generally well mixed; therefore, CVAO can be used to describe the aerosol particles at cloud level.

Overall, $\kappa$ averaged 0.28 , suggesting the presence of organic material in particles. This is consistent with previous model work (Pringle et al., 2010) and field measurements of hygroscopic growth (Schladitz et al., 2011a) done for the location of Cabo Verde. There is a slight increase in $\kappa$ with particle size, indicating the addition of soluble, likely inorganic, material during cloud processing. When looking at the two most different aerosol types, the marine type and dust type2, $\kappa$ values for these periods show no significant difference. On the other hand, dust plumes enhanced particle concentrations in the Aitken, accumulation and coarse modes and therefore increased $N_{\mathrm{CCN}} ; N_{\mathrm{CCN}, 0.30 \%}$ during the strongest observed dust periods is about 2.5 times higher than that during marine periods.

Data availability. The data are available through the World Data Center PANGAEA (https://doi.pangaea.de/10.1594/PANGAEA. 905070, Gong et al., 2019). 
Supplement. The supplement related to this article is available online at: https://doi.org/10.5194/acp-20-1431-2020-supplement.

Author contributions. XG wrote the article with contributions from HW, JV and MvP. KW and XG performed MPSS and APS measurements, and XG performed the data evaluation. KW calibrated MPSS and APS before, during, and after the campaign. FS, HW and $\mathrm{XG}$ performed the $\mathrm{CCN}$ measurements, and $\mathrm{XG}$ performed the data evaluation. SH calibrated $\mathrm{CCN}$ before and after the campaign. Balloon measurements and data evaluation were performed by JV and XG. XG, HW and FS discussed the results and further analysis after the campaign. All co-authors proofread and commented on the article.

Competing interests. The authors declare that they have no conflict of interest.

Special issue statement. This article is part of the special issue "Marine organic matter: from biological production in the ocean to organic aerosol particles and marine clouds (ACP/OS inter-journal SI)". It is not associated with a conference.

Acknowledgements. The work was carried out in the framework of the MarParCloud project. The authors acknowledge the Leibniz Association SAW funding for the project "Marine biological production, organic aerosol particles and marine clouds: a Process Chain (MarParCloud)" (SAW-2016-TROPOS-2). We are grateful to Lucy Carpenter and Katie Read, from the University of York and the Atmospheric Measurement and Observation Facility at the National Centre for Atmospheric Science (NCAS-AMOF), for kindly providing the meteorology data at CVAO.

Financial support. This research has been supported by the Leibniz Association SAW (MarParCloud (grant no. SAW-2016TROPOS-2)).

The publication of this article was funded by the Open Access Fund of the Leibniz Association.

Review statement. This paper was edited by Kimitaka Kawamura and reviewed by two anonymous referees.

\section{References}

Albrecht, B. A.: Aerosols, cloud microphysics, and fractional cloudiness, Science, 245, 1227-1230, 1989.

Allan, J. D., Topping, D. O., Good, N., Irwin, M., Flynn, M., Williams, P. I., Coe, H., Baker, A. R., Martino, M., Niedermeier, N., Wiedensohler, A., Lehmann, S., Müller, K., Herrmann, H., and McFiggans, G.: Composition and properties of atmospheric particles in the eastern Atlantic and impacts on gas phase uptake rates, Atmos. Chem. Phys., 9, 9299-9314, https://doi.org/10.5194/acp-9-9299-2009, 2009.

Andreae, M. and Rosenfeld, D.: Aerosol-cloud-precipitation interactions. Part 1 . The nature and sources of cloud-active aerosols, Earth-Sci. Rev., 89, 13-41, 2008.

Brooks, S. D. and Thornton, D. C.: Marine Aerosols and Clouds, Annu. Rev. Mar. Sci., 10, 289-313, https://doi.org/10.1146/annurev-marine-121916-063148, 2018.

Carpenter, L. J., Fleming, Z. L., Read, K. A., Lee, J. D., Moller, S. J., Hopkins, J. R., Purvis, R. M., Lewis, A. C., Müller, K., Heinold, B., Herrmann, H., Fomba, K. W., van Pinxteren, D., Müller, C., Tegen, I., Wiedensohler, A., Müller, T., Niedermeier, N., Achterberg, E. P., Patey, M. D., Kozlova, E. A., Heimann, M., Heard, D. E., Plane, J. M. C., Mahajan, A., Oetjen, H., Ingham, T., Stone, D., Whalley, L. K., Evans, M. J., Pilling, M. J., Leigh, R. J., Monks, P. S., Karunaharan, A., Vaughan, S., Arnold, S. R., Tschritter, J., Pöhler, D., Frieß, U., Holla, R., Mendes, L. M., Lopez, H., Faria, B., Manning, A. J., and Wallace, D. W. R.: Seasonal characteristics of tropical marine boundary layer air measured at the Cape Verde Atmospheric Observatory, J. Atmos. Chem., 67, 87-140, https://doi.org/10.1007/s10874-011-9206-1, 2010.

Christensen, M. W., Chen, Y.-C., and Stephens, G. L.: Aerosol indirect effect dictated by liquid clouds, J. Geophys. Res.-Atmos., 121, 14636-14650, https://doi.org/10.1002/2016JD025245, 2016.

Clarke, A. D., Li, Z., and Litchy, M.: Aerosol dynamics in the equatorial Pacific marine boundary layer: Microphysics, diurnal cycles and entrainment, Geophys. Res. Lett., 23, 733-736, https://doi.org/10.1029/96gl00778, 1996.

DeMott, P. J., Sassen, K., Poellot, M. R., Baumgardner, D., Rogers, D. C., Brooks, S. D., Prenni, A. J., and Kreidenweis, S. M.: African dust aerosols as atmospheric ice nuclei, Geophys. Res. Lett., 30, 1732, https://doi.org/10.1029/2003GL017410, 2003.

DeMott, P. J., Hill, T. C. J., McCluskey, C. S., Prather, K. A., Collins, D. B., Sullivan, R. C., Ruppel, M. J., Mason, R. H., Irish, V. E., Lee, T., Hwang, C. Y., Rhee, T. S., Snider, J. R., McMeeking, G. R., Dhaniyala, S., Lewis, E. R., Wentzell, J. J. B., Abbatt, J., Lee, C., Sultana, C. M., Ault, A. P., Axson, J. L., Diaz Martinez, M., Venero, I., Santos-Figueroa, G., Stokes, M. D., Deane, G. B., Mayol-Bracero, O. L., Grassian, V. H., Bertram, T. H., Bertram, A. K., Moffett, B. F., and Franc, G. D.: Sea spray aerosol as a unique source of ice nucleating particles, P. Natl. Acad. Sci. USA, 113, 5797-5803, https://doi.org/10.1073/pnas.1514034112, 2016.

Dusek, U., Frank, G., Hildebrandt, L., Curtius, J., Schneider, J., Walter, S., Chand, D., Drewnick, F., Hings, S., Jung, D., Borrmann, S., and Andreae, M. O.: Size matters more than chemistry for cloud-nucleating ability of aerosol particles, Science, 312, 1375-1378, 2006.

Fomba, K. W., Müller, K., van Pinxteren, D., and Herrmann, H.: Aerosol size-resolved trace metal composition in remote northern tropical Atlantic marine environment: case study Cape Verde islands, Atmos. Chem. Phys., 13, 4801-4814, https://doi.org/10.5194/acp-13-4801-2013, 2013.

Fomba, K. W., Müller, K., van Pinxteren, D., Poulain, L., van Pinxteren, M., and Herrmann, H.: Long-term chemical characterization of tropical and marine aerosols at the Cape Verde Atmospheric Observatory (CVAO) from 2007 to 2011, Atmos. 
Chem. Phys., 14, 8883-8904, https://doi.org/10.5194/acp-148883-2014, 2014.

Fuentes, E., Coe, H., Green, D., and McFiggans, G.: On the impacts of phytoplankton-derived organic matter on the properties of the primary marine aerosol - Part 2: Composition, hygroscopicity and cloud condensation activity, Atmos. Chem. Phys., 11, 25852602, https://doi.org/10.5194/acp-11-2585-2011, 2011.

Gama, C., Tchepel, O., Baldasano, J. M., Basart, S., Ferreira, J., Pio, C., Cardoso, J. a., and Borrego, C.: Seasonal patterns of Saharan dust over Cape Verde - a combined approach using observations and modelling, Tellus B, 67, 24410, https://doi.org/10.3402/tellusb.v67.24410, 2015.

Garrison, V. H., Majewski, M. S., Foreman, W. T., Genualdi, S. A., Mohammed, A., and Massey Simonich, S. L.: Persistent organic contaminants in Saharan dust air masses in West Africa, Cape Verde and the eastern Caribbean, Sci. Total Environ., 468-469, 530-543, https://doi.org/10.1016/j.scitotenv.2013.08.076, 2014.

Ginoux, P., Chin, M., Tegen, I., Prospero, J. M., Holben, B., Dubovik, O., and Lin, S.-J.: Sources and distributions of dust aerosols simulated with the GOCART model, J. Geophys. Res.-Atmos., 106, 20255-20273, https://doi.org/10.1029/2000JD000053, 2001.

Ginoux, P., Prospero, J. M., Gill, T. E., Hsu, N. C., and Zhao, M.: Global-scale attribution of anthropogenic and natural dust sources and their emission rates based on MODIS Deep Blue aerosol products, Rev. Geophys., 50, RG3005, https://doi.org/10.1029/2012RG000388, 2012.

Gong, X., Wex, H., Voigtländer, J., Fomba, K. W., Weinhold, K., van Pinxteren, M., Henning, S., Müller, T., Herrmann, H., and Stratmann, F.: Ground-based measurements on aerosol particles at Cape Verde (Sep-Oct 2017), PANGAEA, https://doi.org/10.1594/PANGAEA.905070, 2019.

Gong, X., Wex, H., van Pinxteren, M., Triesch, N., Fomba, K. W., Lubitz, J., Stolle, C., Robinson, T.-B., Müller, T., Herrmann, H., and Stratmann, F.: Characterization of aerosol particles at Cabo Verde close to sea level and at the cloud level Part 2: Ice-nucleating particles in air, cloud and seawater, Atmos. Chem. Phys., 20, 1451-1468, https://doi.org/10.5194/acp20-1451-2020, 2020.

Goudie, A. S. and Middleton, N. J.: Saharan dust storms: nature and consequences, Earth-Sci. Rev., 56, 179-204, https://doi.org/10.1016/S0012-8252(01)00067-8, 2001.

Gysel, M. and Stratmann, F.: WP3 - NA3: In-situ chemical, physical and optical properties of aerosols, Deliverable D3.11: Standardized protocol for $\mathrm{CCN}$ measurements, Tech. rep., available at: http://www.actris.net/Publications/ ACTRISQualityStandards/tabid/11271/language/en-GB/ Default.aspx (last access: 4 February 2020), 2013.

Heinold, B., Tegen, I., Schepanski, K., Tesche, M., Esselborn, M., Freudenthaler, V., Gross, S., Kandler, K., Knippertz, P., Müller, D., Schladitz, A., Toledano, C., Weinzierl, B., Ansmann, A., Althausen, D., Müller, T., Petzold, A., and Wiedensohler, A.: Regional modelling of Saharan dust and biomass-burning smoke, Tellus B, 63, 781-799, https://doi.org/10.1111/j.16000889.2011.00570.x, 2011.

Herenz, P., Wex, H., Henning, S., Kristensen, T. B., Rubach, F., Roth, A., Borrmann, S., Bozem, H., Schulz, H., and Stratmann, F.: Measurements of aerosol and CCN properties in the Mackenzie River delta (Canadian Arctic) during spring-summer transition in May 2014, Atmos. Chem. Phys., 18, 4477-4496, https://doi.org/10.5194/acp-18-4477-2018, 2018.

Hoppel, W., Frick, G., and Larson, R.: Effect of nonprecipitating clouds on the aerosol size distribution in the marine boundary layer, Geophys. Res. Lett., 13, 125-128, https://doi.org/10.1029/GL013i002p00125, 1986.

Hoppel, W. A., Frick, G. M., Fitzgerald, J. W., and Larson, R. E.: Marine boundary layer measurements of new particle formation and the effects nonprecipitating clouds have on aerosol size distribution, J. Geophys. Res.-Atmos., 99, 14443-14459, https://doi.org/10.1029/94JD00797, 1994.

Huang, J., Lin, B., Minnis, P., Wang, T., Wang, X., Hu, Y., Yi, Y., and Ayers, J. K.: Satellite-based assessment of possible dust aerosols semi-direct effect on cloud water path over East Asia, Geophys. Res. Lett., 33, L19802, https://doi.org/10.1029/2006GL026561, 2006.

Jaenicke, R. and Schütz, L.: Comprehensive study of physical and chemical properties of the surface aerosols in the Cape Verde Islands region, J. Geophys. Res.-Oceans, 83, 3585-3599, https://doi.org/10.1029/JC083iC07p03585, 1978.

Kaaden, N., Massling, A., Schladitz, A., Müller, T., Kandler, K., Schütz, L., Weinzierl, B., Petzold, A., Tesche, M., Leinert, S., Deutscher, C., Ebert, M., Weinbruch, S., and Wiedensohler, A.: State of mixing, shape factor, number size distribution, and hygroscopic growth of the Saharan anthropogenic and mineral dust aerosol at Tinfou, Morocco, Tellus B, 61, 51-63, https://doi.org/10.1111/j.1600-0889.2008.00388.x, 2009.

Kalivitis, N., Kerminen, V.-M., Kouvarakis, G., Stavroulas, I., Bougiatioti, A., Nenes, A., Manninen, H. E., Petäjä, T., Kulmala, M., and Mihalopoulos, N.: Atmospheric new particle formation as a source of $\mathrm{CCN}$ in the eastern Mediterranean marine boundary layer, Atmos. Chem. Phys., 15, 9203-9215, https://doi.org/10.5194/acp-15-9203-2015, 2015.

Kandler, K., SchüTz, L., Deutscher, C., Ebert, M., Hofmann, H., JäCkel, S., Jaenicke, R., Knippertz, P., Lieke, K., Massling, A., Petzold, A., Schladitz, A., Weinzierl, B., Wiedensohler, A., Zorn, S., and Weinbruch, S.: Size distribution, mass concentration, chemical and mineralogical composition and derived optical parameters of the boundary layer aerosol at Tinfou, Morocco, during SAMUM 2006, Tellus B, 61, 32-50, https://doi.org/10.1111/j.1600-0889.2008.00385.x, 2009.

Kandler, K., Lieke, K., Benker, N., Emmel, C., Küpper, M., MüllerEbert, D., Ebert, M., Scheuvens, D., Schladitz, A., Schütz, L., and Weinbruch, S.: Electron microscopy of particles collected at Praia, Cape Verde, during the Saharan Mineral Dust Experiment: particle chemistry, shape, mixing state and complex refractive index, Tellus B, 63, 475-496, https://doi.org/10.1111/j.16000889.2011.00550.x, 2011a.

Kandler, K., Schütz, L., Jäckel, S., Lieke, K., Emmel, C., MüllerEbert, D., Ebert, M., Scheuvens, D., Schladitz, A., S̆egvić, B., Wiedensohler, A., and Weinbruch, S.: Ground-based off-line aerosol measurements at Praia, Cape Verde, during the Saharan Mineral Dust Experiment: microphysical properties and mineralogy, Tellus B, 63, 459-474, https://doi.org/10.1111/j.16000889.2011.00546.x, 2011b.

Karydis, V. A., Kumar, P., Barahona, D., Sokolik, I. N., and Nenes, A.: On the effect of dust particles on global cloud condensation nuclei and cloud droplet number, J. Geophys. Res.-Atmos., 116, D23204, https://doi.org/10.1029/2011JD016283, 2011. 
Köhler, H.: The nucleus in and the growth of hygroscopic droplets, T. Faraday Soc., 32, 1152-1161, 1936.

Kristensen, T. B., Müller, T., Kandler, K., Benker, N., Hartmann, M., Prospero, J. M., Wiedensohler, A., and Stratmann, F.: Properties of cloud condensation nuclei $(\mathrm{CCN})$ in the trade wind marine boundary layer of the western North Atlantic, Atmos. Chem. Phys., 16, 2675-2688, https://doi.org/10.5194/acp-162675-2016, 2016.

Lieke, K., Kandler, K., Scheuvens, D., Emmel, C., Von Glahn, C., Petzold, A., Weinzierl, B., Veira, A., Ebert, M., Weinbruch, S., and Schütz, L.: Particle chemical properties in the vertical column based on aircraft observations in the vicinity of Cape Verde Islands, Tellus B, 63, 497-511, https://doi.org/10.1111/j.16000889.2011.00553.x, 2011.

Modini, R. L., Frossard, A. A., Ahlm, L., Russell, L. M., Corrigan, C. E., Roberts, G. C., Hawkins, L. N., Schroder, J. C., Bertram, A. K., Zhao, R., Lee, A. K. Y., Abbatt, J. P. D., Lin, J., Nenes, A., Wang, Z., Wonaschütz, A., Sorooshian, A., Noone, K. J., Jonsson, H., Seinfeld, J. H., Toom-Sauntry, D., Macdonald, A. M., and Leaitch, W. R.: Primary marine aerosol-cloud interactions off the coast of California, J. Geophys. Res.-Atmos., 120, 42824303, https://doi.org/10.1002/2014JD022963, 2015.

Nie, W., Ding, A., Wang, T., Kerminen, V.-M., George, C., Xue, L., Wang, W., Zhang, Q., Petäjä, T., Qi, X., Gao, X., Wang, X., Yang, X., Fu, C., and Kulmala, M.: Polluted dust promotes new particle formation and growth, Sci. Rep., 4, 6634, https://doi.org/10.1038/srep06634, 2014.

Petters, M. D. and Kreidenweis, S. M.: A single parameter representation of hygroscopic growth and cloud condensation nucleus activity, Atmos. Chem. Phys., 7, 1961-1971, https://doi.org/10.5194/acp-7-1961-2007, 2007.

Pfeifer, S., Müller, T., Weinhold, K., Zikova, N., Martins dos Santos, S., Marinoni, A., Bischof, O. F., Kykal, C., Ries, L., Meinhardt, F., Aalto, P., Mihalopoulos, N., and Wiedensohler, A.: Intercomparison of 15 aerodynamic particle size spectrometers (APS 3321): uncertainties in particle sizing and number size distribution, Atmos. Meas. Tech., 9, 1545-1551, https://doi.org/10.5194/amt-9-1545-2016, 2016.

Prather, K. A., Bertram, T. H., Grassian, V. H., Deane, G. B., Stokes, M. D., DeMott, P. J., Aluwihare, L. I., Palenik, B. P., Azam, F., Seinfeld, J. H., Moffet, R. C., Molina, M. J., Cappa, C. D., Geiger, F. M., Roberts, G. C., Russell, L. M., Ault, A. P., Baltrusaitis, J., Collins, D. B., Corrigan, C. E., CuadraRodriguez, L. A., Ebben, C. J., Forestieri, S. D., Guasco, T. L., Hersey, S. P., Kim, M. J., Lambert, W. F., Modini, R. L., Mui, W., Pedler, B. E., Ruppel, M. J., Ryder, O. S., Schoepp, N. G., Sullivan, R. C., and Zhao, D.: Bringing the ocean into the laboratory to probe the chemical complexity of sea spray aerosol, P. Natl. Acad. Sci. USA, 110, 7550-7555, https://doi.org/10.1073/pnas.1300262110, 2013.

Pringle, K. J., Tost, H., Pozzer, A., Pöschl, U., and Lelieveld, J.: Global distribution of the effective aerosol hygroscopicity parameter for CCN activation, Atmos. Chem. Phys., 10, 52415255, https://doi.org/10.5194/acp-10-5241-2010, 2010.

Prospero, J. M., Ginoux, P., Torres, O., Nicholson, S. E., and Gill, T. E.: Environmental characterization of global sources of atmospheric soil dust identified with the nimbus 7 total ozone mapping spectrometer (TOMS) absorbing aerosol product, Rev. Geo- phys., 40, 2-1-2-31, https://doi.org/10.1029/2000RG000095, 2002.

Quinn, P. K., Collins, D. B., Grassian, V. H., Prather, K. A., and Bates, T. S.: Chemistry and Related Properties of Freshly Emitted Sea Spray Aerosol, Chem. Rev., 115, 4383-4399, https://doi.org/10.1021/cr500713g, 2015.

Quinn, P. K., Coffman, D. J., Johnson, J. E., Upchurch, L. M., and Bates, T. S.: Small fraction of marine cloud condensation nuclei made up of sea spray aerosol, Nat. Geosci., 10, 674, https://doi.org/10.1038/ngeo3003, 2017.

Roberts, G. C. and Nenes, A.: A Continuous-Flow Streamwise Thermal-Gradient $\mathrm{CCN}$ Chamber for Atmospheric Measurements, Aerosol Sci. Technol., 39, 206-221, https://doi.org/10.1080/027868290913988, 2005.

Rolph, G.: Real-time environmental applications and display system (READY) website, available at: https://www.ready.noaa. gov/index.php (last access: 4 February 2020), 2003.

Rosati, B., Gysel, M., Rubach, F., Mentel, T. F., Goger, B., Poulain, L., Schlag, P., Miettinen, P., Pajunoja, A., Virtanen, A., Klein Baltink, H., Henzing, J. S. B., Größ, J., Gobbi, G. P., Wiedensohler, A., Kiendler-Scharr, A., Decesari, S., Facchini, M. C., Weingartner, E., and Baltensperger, U.: Vertical profiling of aerosol hygroscopic properties in the planetary boundary layer during the PEGASOS campaigns, Atmos. Chem. Phys., 16, 7295-7315, https://doi.org/10.5194/acp-16-7295-2016, $2016 \mathrm{a}$.

Rosati, B., Herrmann, E., Bucci, S., Fierli, F., Cairo, F., Gysel, M., Tillmann, R., Größ, J., Gobbi, G. P., Di Liberto, L., Di Donfrancesco, G., Wiedensohler, A., Weingartner, E., Virtanen, A., Mentel, T. F., and Baltensperger, U.: Studying the vertical aerosol extinction coefficient by comparing in situ airborne data and elastic backscatter lidar, Atmos. Chem. Phys., 16, 4539-4554, https://doi.org/10.5194/acp-16-4539-2016, 2016 b.

Rose, D., Gunthe, S. S., Mikhailov, E., Frank, G. P., Dusek, U., Andreae, M. O., and Pöschl, U.: Calibration and measurement uncertainties of a continuous-flow cloud condensation nuclei counter (DMT-CCNC): CCN activation of ammonium sulfate and sodium chloride aerosol particles in theory and experiment, Atmos. Chem. Phys., 8, 1153-1179, https://doi.org/10.5194/acp8-1153-2008, 2008.

Salvador, P., Artíñano, B., Molero, F., Viana, M., Pey, J., Alastuey, A., and Querol, X.: African dust contribution to ambient aerosol levels across central Spain: Characterization of long-range transport episodes of desert dust, Atmos. Res., 127, 117-129, https://doi.org/10.1016/j.atmosres.2011.12.011, 2013.

Salvador, P., Almeida, S. M., Cardoso, J., Almeida-Silva, M., Nunes, T., Cerqueira, M., Alves, C., Reis, M. A., Chaves, P. C., Artíñano, B., and Pio, C.: Composition and origin of $\mathrm{PM}_{10}$ in Cape Verde: Characterization of longrange transport episodes, Atmos. Environ., 127, 326-339, https://doi.org/10.1016/j.atmosenv.2015.12.057, 2016.

Sassen, K., DeMott, P. J., Prospero, J. M., and Poellot, M. R.: Saharan dust storms and indirect aerosol effects on clouds: CRYSTAL-FACE results, Geophys. Res. Lett., 30, 1633, https://doi.org/10.1029/2003GL017371, 2003.

Schladitz, A., Müller, T., Nordmann, S., Tesche, M., Groß, S., Freudenthaler, V., Gasteiger, J., and Wiedensohler, A.: In situ aerosol characterization at Cape Verde, Part 2: Parameterization of relative humidity- and wavelength- 
dependent aerosol optical properties, Tellus B, 63, 549-572, https://doi.org/10.1111/j.1600-0889.2011.00568.x, 2011a.

Schladitz, A., Müller, T., Nowak, A., Kandler, K., Lieke, K., Massling, A., and Wiedensohler, A.: In situ aerosol characterization at Cape Verde, Part1: Particle number size distributions, hygroscopic growth and state of mixing of mrine and Saharan dust aerosol, Tellus B, 63, 531-548, https://doi.org/10.1111/j.16000889.2011.00569.x, 2011b.

Seinfeld, J. H. and Pandis, S. N.: Atmospheric chemistry and physics: from air pollution to climate change, John Wiley \& Sons, 2016.

Shao, Y., Wyrwoll, K.-H., Chappell, A., Huang, J., Lin, Z., McTainsh, G. H., Mikami, M., Tanaka, T. Y., Wang, $\mathrm{X}$, and Yoon, S.: Dust cycle: An emerging core theme in Earth system science, Aeolian Res., 2, 181-204, https://doi.org/10.1016/j.aeolia.2011.02.001, 2011.

Stein, A. F., Draxler, R. R., Rolph, G. D., Stunder, B. J. B., Cohen, M. D., and Ngan, F.: NOAA's HYSPLIT Atmospheric Transport and Dispersion Modeling System, B. Am. Meteorol. Soc., 96, 2059-2077, https://doi.org/10.1175/bams-d-14-00110.1, 2015.

Stocker, T.: Climate change 2013: the physical science basis: Working Group I contribution to the Fifth assessment report of the Intergovernmental Panel on Climate Change, Cambridge University Press, 2014.

Swap, R., Garstang, M., Greco, S., Talbot, R., and Kallberg, P.: Saharan dust in the Amazon Basin, Tellus B, 44, 133-149, https://doi.org/10.1034/j.1600-0889.1992.t01-1-00005.x, 1992.

Tanaka, T. Y. and Chiba, M.: A numerical study of the contributions of dust source regions to the global dust budget, Global Planet. Change, 52, 88-104, https://doi.org/10.1016/j.gloplacha.2006.02.002, 2006.

Tesche, M., Ansmann, A., Müller, D., Althausen, D., Engelmann, R., Freudenthaler, V., and Groß, S.: Vertically resolved separation of dust and smoke over Cape Verde using multiwavelength Raman and polarization lidars during Saharan Mineral Dust Experiment 2008, J. Geophys. Res.-Atmos., 114, D13202, https://doi.org/10.1029/2009JD011862, 2009.

Twomey, S.: Pollution and the planetary albedo, Atmos. Environ., 8, 1251-1256, 1974.

van Pinxteren, M., Fomba, K. W., Triesch, N., Stolle, C., Wurl, O., Bahlmann, E., Gong, X., Voigtländer, J., Wex, H., Robinson, T.-B., Barthel, S., Zeppenfeld, S., Hoffmann, E. H., Roveretto, M., Li, C., Grosselin, B., Daële, V., Senf, F., van Pinxteren, D., Manzi, M., Zabalegui, N., Frka, S., Gašparović, B., Pereira, R., Li, T., Wen, L., Li, J., Zhu, C., Chen, H., Chen, J., Fiedler, B., von Tümpling, W., Read, K. A., Punjabi, S., C. Lewis, A. C., Hopkins, J. R., Carpenter, L. J., Peeken, I., Rixen, T., SchulzBull, D., Monge, M. E., Mellouki, A., George, C., Stratmann, F., and Herrmann, H.: Marine organic matter in the remote environment of the Cape Verde Islands - An introduction and overview to the MarParCloud campaign, Atmos. Chem. Phys. Discuss., https://doi.org/10.5194/acp-2019-997, in review, 2019.

von der Weiden, S.-L., Drewnick, F., and Borrmann, S.: Particle Loss Calculator - a new software tool for the assessment of the performance of aerosol inlet systems, Atmos. Meas. Tech., 2, 479-494, https://doi.org/10.5194/amt-2-479-2009, 2009.
Warneck, P.: Chemistry of the natural atmosphere, 2nd Edn., vol. 71, ISBN 10 0127356320, Elsevier, Academic Press, London, UK, 1999.

Weinzierl, B., Petzold, A., Esselborn, M., Wirth, M., Rasp, K., Kandler, K., Schütz, L., Koepke, P., and Fiebig, M.: Airborne measurements of dust layer properties, particle size distribution and mixing state of Saharan dust during SAMUM 2006, Tellus B, 61, 96-117, https://doi.org/10.1111/j.1600-0889.2008.00392.x, 2009.

Wex, H., Dieckmann, K., Roberts, G. C., Conrath, T., Izaguirre, M. A., Hartmann, S., Herenz, P., Schäfer, M., Ditas, F., Schmeissner, T., Henning, S., Wehner, B., Siebert, H., and Stratmann, F.: Aerosol arriving on the Caribbean island of Barbados: physical properties and origin, Atmos. Chem. Phys., 16, 14107-14130, https://doi.org/10.5194/acp-16-14107-2016, 2016.

Wiedensohler, A.: An approximation of the bipolar charge distribution for particles in the submicron size range, J. Aerosol Sci., 19 , 387-389, https://doi.org/10.1016/0021-8502(88)90278-9, 1988.

Wiedensohler, A., Birmili, W., Nowak, A., Sonntag, A., Weinhold, K., Merkel, M., Wehner, B., Tuch, T., Pfeifer, S., Fiebig, M., Fjäraa, A. M., Asmi, E., Sellegri, K., Depuy, R., Venzac, H., Villani, P., Laj, P., Aalto, P., Ogren, J. A., Swietlicki, E., Williams, P., Roldin, P., Quincey, P., Hüglin, C., Fierz-Schmidhauser, R., Gysel, M., Weingartner, E., Riccobono, F., Santos, S., Grüning, C., Faloon, K., Beddows, D., Harrison, R., Monahan, C., Jennings, S. G., O’Dowd, C. D., Marinoni, A., Horn, H.-G., Keck, L., Jiang, J., Scheckman, J., McMurry, P. H., Deng, Z., Zhao, C. S., Moerman, M., Henzing, B., de Leeuw, G., Löschau, G., and Bastian, S.: Mobility particle size spectrometers: harmonization of technical standards and data structure to facilitate high quality long-term observations of atmospheric particle number size distributions, Atmos. Meas. Tech., 5, 657-685, https://doi.org/10.5194/amt-5-657-2012, 2012.

Wiedensohler, A., Wiesner, A., Weinhold, K., Birmili, W., Hermann, M., Merkel, M., Müller, T., Pfeifer, S., Schmidt, A., Tuch, T., Velarde, F., Quincey, P., Seeger, S., and Nowak, A.: Mobility particle size spectrometers: Calibration procedures and measurement uncertainties, Aerosol Sci. Technol., 52, 146-164, https://doi.org/10.1080/02786826.2017.1387229, 2018.

Wilson, T. W., Ladino, L. A., Alpert, P. A., Breckels, M. N., Brooks, I. M., Browse, J., Burrows, S. M., Carslaw, K. S., Huffman, J. A., Judd, C., Kilthau, W. P., Mason, R. H., McFiggans, G., Miller, L. A., Najera, J. J., Polishchuk, E., Rae, S., Schiller, C. L., Si, M., Temprado, J. V., Whale, T. F., Wong, J. P. S., Wurl, O., Yakobi-Hancock, J. D., Abbatt, J. P. D., Aller, J. Y., Bertram, A. K., Knopf, D. A., and Murray, B. J.: A marine biogenic source of atmospheric ice-nucleating particles, Nature, 525, 234-238, https://doi.org/10.1038/nature14986, 2015. 